\title{
Geçmişin İzleriyle Amasya Gümüşlü Cami
}

\author{
Amasya Gümüşlü Mosque with the Traces of the Past
}

\section{Fazilet Koçyiğit ${ }^{*}$}

\section{Öz}

Osmanlı Devleti zamanında önemli kentlerden biri olan Amasya'da çok sayıda Osmanlı eseri bulunmaktadır. Bu eserlerden en erken tarihli olan Gümüşlü Cami, yapılan büyük çaplı onarımlar sebebiyle özgün hâlinden uzaklaşmıştır. Mimarisi ve bezemeleri, bu onarımlarla değişime uğrayan cami hakkında spesifik bir çalışma yapılmamıştır. Amasya kent dokusunda ve belleğinde önemli bir yere sahip olan ve aktif bir şekilde kullanılmaya devam eden cami ile ilgili cevaplanması gereken sorular bulunmaktadır.

Çalışmanın başında camiye gidilip yerinde incelemeler yapılmıştır. Daha sonra literatür araştırması yapılmış ve eser hakkında spesifik bir çalışmanın olmadığı görülmüştür. Literatür araştırması sonrasında, Samsun Vakıflar Bölge Müdürlüğü’nden esere dair raporlar ve eski fotoğraflar alınarak alanda yeniden incelemeler yapılmıştır. Tüm bu araştırmalar neticesinde eserin geçirmiş olduğu değişimler tespit edilmiş ve caminin özgün hâline dair veriler çalışılmıştır. Amasya’nın bir parçası olan, yaşayanlarına hizmet, tarihine tanıklık eden Gümüşlü Cami'nin geçmişten gelen izleriyle belgelenmesi ve yaşatılması çalışmanın öncelikli amacıdır.

Bu çalışmada sahada yapılan incelemeler, literatür araştırmaları, belgeler ve eski fotoğraflardan yola çıkılarak caminin özgün hâlinde zaviyeli bir cami olduğu ileri sürülmüştür. Yapılan çalışmalar sonrasında, caminin sadece mimarisinde değil bezemelerinde de değişimler olduğu görülmüştür. Elde edilen eski fotoğraflar vasıtasıyla, bezemelerin konu ve üslubundan yola çıkılarak caminin özgün tasvirlerinin, R. Arık'ın da belirttiği gibi, 1870'li yıllarda halk sanatçısı Zileli Emin Usta tarafından yapılmış olabileceği iddia edilmiştir.

\section{Anahtar Kelimeler}

Gümüşlü Cami, Geç Dönem Bezemeleri, Duvar Resmi, Zaviye, Osmanlı Mimarisi

\section{Abstract}

There are many Ottoman buildings in Amasya, which was one of the important cities during the Ottoman period. Gümüşlü Mosque, which was the earliest of these buildings, has moved away from its original form due to major repairs. There has been no specific study about the mosque whose architecture and ornaments were changed by these repairs. The mosque, which has an important place in the urban fabric and memory of Amasya and continues to be used actively, has questions that need to be answered.

In this study, firstly, the mosque was visited and investigations were made on site. After the investigations on the field, a literature search was done and it was seen that there was no specific study about the Gümüşlü Mosque. The investigations were done again on the field by taking the reports and old photographs about the mosque from the Samsun Regional Directorate of Foundations after the literature research. As a result of all these examinations, the changes in the mosque

* Sorumlu Yazar: Fazilet Koçyiğit (Doç. Dr.) Amasya Üniversitesi, Mimarlık Fakültesi, Mimarlık Bölümü. Amasya, Türkiye. E-posta: fazilet.kocyigit@amasya.edu.tr ORCID: 0000000243523413

Attf: Kocyigit, Fazilet. “Geçmişin İzleriyle Amasya Gümüşlü Cami.” Art-Sanat, 17(2022): 299-326.

https://doi.org/10.26650/artsanat.2022.17.115626 
were determined and the data regarding the original state of the mosque were systematically explained in this study.

In this study, it has been suggested that the mosque was originally a zawiya, based on the studies in the field, literature researches, documents and old photographs. After the investigations, it was observed that there were changes not only in the architecture but also in the ornaments. Based on the subject and style of the ornaments, it has been claimed that the original ornaments of the mosque were made by Zileli Emin Usta in the 1870 s.

Keywords

Gümüşlü Mosque, Late Period Ornaments, Wall Painting, Zawiya, Ottoman Architecture

\section{Extended Summary}

Amasya has hosted 14 civilizations in its long history. During the period of the Ottoman Empire, which was among these 14 civilizations, many buildings were built in the city. Gümüşlü Mosque, which was the earliest of these buildings, has moved away from its original form due to major repairs. Brief information about the Gümüşlü Mosque is given in the theses and articles written by some researchers but there is no specific study about the mosque whose architecture and ornaments were changed by these repairs. The mosque which has an important place in the urban fabric and memory of Amasya and continuesto be used actively, has questions that need to be answered.

Before I started studying, I went to the mosque and made on-site investigations. In the literature research carried out after the investigations on the field, it was seen that no specific study about the Gümüşlü Mosque. The investigations were done again on the field by taking the reports and old photographs about the mosque from the Samsun Regional Directorate of Foundations after the literature research. As a result of all these examinations, the changes in the mosque were determined and the data regarding the original state of the mosque were systematically explained in this study. In the light of the information given by the local historian H. Hüsameddin; it is known that the wooden material was used in the first construction of the building and that the present-day masonry structure was built instead of this wooden mosque, which was destroyed by a fire. However, this masonry structure, which has survived to the present day, has questions that need to be resolved due to the major repairs. The first of these questions; Is Gümüşlü Mosque a zawiya?

Although Gümüşlü Mosque was built in the $15^{\text {th }}$ century, it also shows the features of the next century due to the major repairs. According to the reports we have obtained; it was determined that the east and west facades of the mosque were rebuilt during the repairs made in 1986. As can be seen in the survey drawings and photographs dated 1979 taken from Samsun Regional Directorate of Foundations, the upper part of the tabhane rooms (lodge) on the east and west facades is covered with a sloping roof, and this roof is built at the lower level from the roof of the sanctuary 
section to provide a two-story appearance. At the present day, it is seen that these facades are raised to the level of sanctuary section roof.

The narthex of the mosque with wooden carcasses was built in 1903 . Due to the central dome of the narthex, which was placed on the recessed arch of the portal incorrectly, damages occurred on the portal largely. It could not be obtained any data about the original form of the narthex, however, we can claim that the narthex was originally built with masonry material considering that the Gümüşlü Mosque was built masonry and the narthex of the Mehmed Pasha and Beyazıd Pasha Zawiyah, which was built in the $15^{\text {th }}$ century. It was given rise to thought the narthex was the higher in the original form by the reason of it was cut off the recessed arch of the portal and massive arches on the north facades.

It could not obtain any data about the original roof of the building. It was built a wooden carcass cone on the octagonal pulley at the present day. We can assert that the original roof of the mosque was a dome considering that the Ottoman roofs were generally dome and the roofs of early period mosques in Amasya. Although there is no information about when today's roof was made, based on the similarity of construction techniques we can think that the roof of the sanctuary section was made in 1903 repairs, like the narthex.

Gümüşlü Mosque which lost its original form due to the major repairs was changed greatly as not only the architectural features but also ornaments. The present-day ornaments in the sanctuary section of the mosque were made during the 1960s repairs. Through the old photographs, we can obtain information about the ornaments programme and motives of the mosque before these repairs. Based on these documents, we can say that the ornaments of the mosque were Baroque influenced before the repairs.

The original ornaments of the mosque that have not reached the present day; shows late period characteristics in terms of ornament programme, subjects and style. We can assert that the ornaments of the Gümüşlü Mosque were made in the 1870s by the local artist Emin from Zile based on the stylistic features of ornaments are similar to the works of local artist Emin from Zile and the mentioned local artist made ornaments in Amasya in the 1870s. The contribution of the Gümüşlü Mosque, which has under gone great changes as a result of major repairs, to the urban fabric and memory of Amasya is undeniable. Since we can not undo the interventions, we hope that this study, which was carried out to document the original form of the Gümüşlü Mosque, will guide future generations. 


\section{Giriş}

Orta Karadeniz Bölgesi’nde Yeşilırmak Nehri kıyısına kurulmuş olan Amasya, uzun tarihî geçmişi içerisinde on dört medeniyete ev sahipliği yapmıştır. Tarihî geçmişi MÖ 3000 yıllarına kadar uzanan şehrin ilk olarak kimler tarafından kurulduğu kesin olarak bilinmemekle birlikte Hitit Konfederasyonu'nu oluşturan on üç şehir devletinden biri olduğu tespit edilmiştir. Bir süre Pontus Krallığı'na da başkentlik yapan Amasya, MÖ 70 yılında Roma topraklarına dâhil edilmiş ve Batı Roma İmparatorluğu'nun yıkılmasının ardından Doğu Roma İmparatorluğu (Bizans Devleti) hâkimiyetinde askerî bir eyalet olarak varlığını sürdürmüştür. Şehrin Türk hâkimiyetine girmesi Danişmentliler zamanında gerçekleşmiştir. Bir süre Danişmentli Beyliği'ne başkentlik yapan şehir, Sultan I. Mesud zamanında Anadolu Selçuklu Devleti'nin hâkimiyetine girmiştir ${ }^{1}$. 1398 yılında Amasya'yı Osmanlı topraklarına katan Sultan Y1ldırım Beyazıd, kentin idaresini oğlu Çelebi Mehmed'e bırakmıştır².

\section{Yapının Konumu, İnşa ve Onarım Tarihçesi}

Amasya il merkezinde yer alan eser, tapunun 1041 ada ve 1 parselinde kayıtlı olup mülkiyeti Vakıflar Genel Müdürlüğü’ne aittir. Cami, önceleri Gümüşlüzade Mahallesi olarak anılan, günümüzde ise Mehmed Paşa Mahallesi olarak adlandırılan mahallede, Atatürk ve Mehmed Paşa Caddeleri’nin kesiştiği köşededir.

Osmanlı Devleti'nin, şehzadeler şehri olan Amasya'da yaptırdığı bu eser, deprem, yangın gibi felaketlerin yanı sıra zamanın yıkıcılığına da maruz kalmış ve bu uzun tarihi içinde birçok onarım aşamasından geçmiştir. Caminin ilk inşa tarihine dair bilgileri yerel bir tarihçi olan Abdizade Hüseyin Hüsameddin'den öğrenmekteyiz. Bu kaynağa göre; Gümüşlüzade Taceddin Mahmud Çelebi, M 1325 yılında bir cami yaptırmış ve M 1327 yılında caminin vakıflarını tanzim etmiştir. Daha sonra torunu Şemseddin Ahmed Çelebi, camiye, Helkıs bahçesini vakfetmiş ve bu vakfiyede caminin ismi "Taciye Camii" olarak geçmiştir ${ }^{3}$. İlerleyen zamanlarda depremlerden zarar gören eser, M 1415 yılında Gümüşlüzade Ahmed Paşa tarafından onartılmış ancak yapı geçirdiği bir yangın sonrasında kullanılmaz duruma gelince M 1485 yılında Ahmed Paşazade Defterdar Ahmed Bey bin Abdullah Bey tarafindan kâgir olarak yeniden inşa ettirilmiştir. Bu tarihte yapının batı tarafına bir de minare eklenerek vakıfları tanzim olunmuştur. Tarihçi H. Hüsameddin' in, yapının kâgir olarak yeniden inşa edildiğini belirtmesi, eserin orijinalinde ahşaptan olabileceğini düşündürmektedir. Buna ek olarak Mustafa Vazıh bin İsmail Amasi, ahşap malzeme ile yapılmış olan bu caminin yıkılarak yerine kâgir caminin yapılmış olduğunu belirtmesi de düşüncemizi

1 Füruzan Kınal, Eski Anadolu Tarihi (Ankara, Türk Tarih Kurumu Yayınları, 1962), 113.

2 İlhan Şahin ve Feridun Emecen, “Amasya”, TDV İslam Ansiklopedisi, c. 3 (İstanbul: Türkiye Diyanet Vakfı Yayınlar1, 1991), 1-4.

3 Abdi-zade Hüseyin Hüsameddin, Amasya Tarihi (Amasya: Amasya Belediyesi Kültür Yayınları, 1986), 134. 
doğrulamaktadır ${ }^{4}$. Bu tarihte caminin taç kapısının üzerine eklenen ve günümüze kadar gelen sülüs hatla yazılmış Farsça kitabesi şu şekildedir:

\author{
"Şud tamam in mescid-i cami be-tevhiki Hûda \\ der zaman-i Padişâh-i adil daniş - pezir \\ iptida-yi in bina ba-hayr-i Ahmed Bey be - hun \\ lik tariheş bud kad temme cami-i kebir"
}

Tercümesi: “ Bu mescid-i camii Allah'ın yardımıyla, ilim seven padişahın zamanında tamam oldu. Bu binaya başlayan Ahmed Bey'i hayırla yad et. Lâkin anın tarihi 890 oldu"s.

H. Hüsameddin, kitabenin birinci ve ikinci mısralarının ebced hesabıyla H 885 ve 890 'a tekabül ettiğini belirtmiştir ${ }^{6}$. M 1480 ve 1485 yıllarına denk gelen bu tarihler, yapının başlangıç ve bitiş yıllarını göstermektedir.

Eşkiyaların çıkarmış olduğu yangınlardan ve depremlerden zarar gören eseri, M 1602 yılında, kitabede adı geçen Ahmed Bey'in torunlarından Beylerbeyi Şemseddin Paşa tamir ettirip vakıflarını tanzim ettirmiştir? ${ }^{7}$ M 1612 yılında çıkan bir yangınla yeniden tahrip olan eseri, M 1688 yılında Gümüşlüzade İbrahim Bey tamir ettirerek eseri bugünkü görünümüne kavuşturmuştur ${ }^{8}$. Devamlı bir şekilde deprem ve yangınlara maruz kalan eser, M 1720 yılında da yanmış, bunun üzerine mütevelli el-Hâc Mustafa Ağa, M 1721'de yapıyı yeniden onartmıştır. M 1822 yılında âyândan Rahtvan Paşazâde el Hâc Ali Bey, caminin vaiz kürsüsünü yaptırmış ve dükkânlarını da bu caminin kürsü şeyhliğine vakfetmiştir9 1903 yılında caminin son cemaat mahalline günümüzdeki ahşap sundurma eklenmiştirir ${ }^{10}$ (G. 1).

4 Gediz Urak, “Amasya’nın Türk Devri Şehir Dokusu ve Yapılarının Analiz ve Değerlendirilmesi” (Doktora Tezi, Gazi Üniversitesi, 1994), 71-72.

5 Urak, “Amasya’nın Türk Devri Şehir Dokusu ve Yapılarının Analiz ve Değerlendirilmesi”, 70.

6 Abdi-zade Hüseyin Hüsameddin, Amasya Tarihi, 135.

7 Abdi-zade Hüseyin Hüsameddin, Amasya Tarihi, 135.

8 V.G.M. 2002: 1361 say1l yazıs1.

9 Abdi-zade Hüseyin Hüsameddin, Amasya Tarihi, 135.

10 V.G.M. 2002: 1361 sayılı yazıs1. 


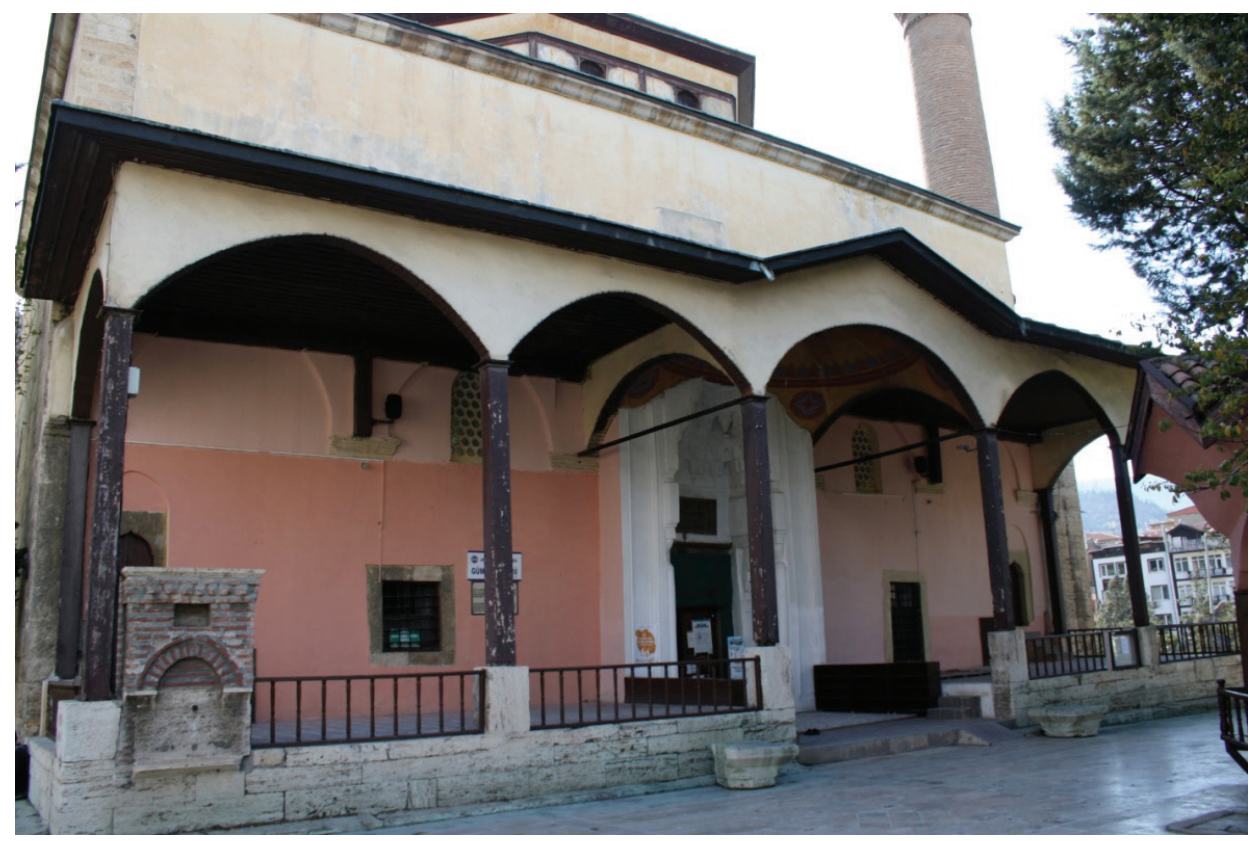

G. 1: Caminin 1903 yılında eklenen günümüzdeki son cemaat mahalli (F. Koçyiğit, 2020)

Eser, 1953 yılında Hürrem Arpacıoğlu tarafindan onartılmıştır. Bu onarımda son cemaat mahallinin çatısı tamir ettirilmiş ve doğusundaki ahşaptan yapılmış ikinci kat kaldırılmış, yan kanatlara camekân eklenmiş, sıva, döşeme, boya, badana vb. bakımlar yapılmışıır ${ }^{11}$. Caminin harim kısmında bulunan mavi, kırmızı ve sarı renkli kalemişleri 1960 yılındaki onarımlarda eklenmiştir ${ }^{12} .1939$ yılında yaşanan deprem sonrasında zarar gören eserin onarılması için halk tarafindan, 1981 yılında V.G.M.'ye restorasyon talebinde bulunulmuştur. Bu talep yazısında caminin hayırseverler tarafindan yaptırılan onarımlarla ayakta kaldığı ancak yetersiz kalan bu tamiratların esaslı bir şeklide yapılmasının gerektiği; aksi takdirde hâlen ibadete açık olan caminin cemaatin başına yıkılacağı belirtilmiştir ${ }^{13} .1981$ yılında onarıma duyulan ihtiyaç nedeniyle cami, uzun süre ibadete kapalı tutulmuştur. 1984 yılında Vakıflar Bölge Müdürlüğü tarafından başlatılan onarım çalışmaları 1989 yılına kadar sürmüştür. Yapılan restorasyonlar sonrasında cami içinde yer alan Amasya manzarası ve Edirne Selimiye Cami tasviri gibi kalemişi bezemeler de kaldırılmıştır ${ }^{14}$. 1986 yılında V.G.M. tarafından yapılan onarımlarda doğu cephe de sıva ile kapatılmış ve üst pencereleri açığa çıkarılmıştır. $\mathrm{Bu}$ onarımlar esnasında doğu ve batı cephelerinin farklı kotlara kadar yıkıldığ 1 ve daha sonra yeniden yapıldığı anlaşılmıştır ${ }^{15}$. 1986 yılında çevreyolu bağlantısı yap-

11 Urak, “Amasya’nın Türk Devri Şehir Dokusu ve Yapılarının Analiz ve Değerlendirilmesi”, 72.

12 V.G.M. 1986: 05.00 / 15 numaralı dosya.

13 V.G.M. 1981: 234 numaralı belge.

14 Hüseyin Menç, Tarih İçinde Amasya (Amasya: Amasya Belediyesi Yayınları, 2014), 92.

15 V.G.M. 1986: 977 numaralı belge. 
mak amacıyla caminin çevresindeki baraka ve tescilsiz binalar yıkılarak cami açığa çıkarılmıştır ${ }^{16}$. 1986 ve sonrasında caminin tavanı, döşemeleri, kalemişleri, mahfili, şadırvanı, minaresi gibi mimari öğeleri ihtiyaç dâhilinde onarılmıştır.

\section{Yapının Tanımı}

Kesme taş malzeme ile inşa edilen cami, kare planlı olup caminin üzeri ahşap çatkılı sekizgen bir kasnağa oturan külah ile örtülmüştür. Sonraki dönem onarımlarına ait olan bu külahın kasnağının her bir yüzeyinde ikişer adet dikdörtgen formlu pencere yer almaktadır. Külah eteğinde de ahşap parmaklıklı dar bir galeri katı bulunmaktadır. Külaha geçiş pandantiflerle sağlanmıştır (G. 2).

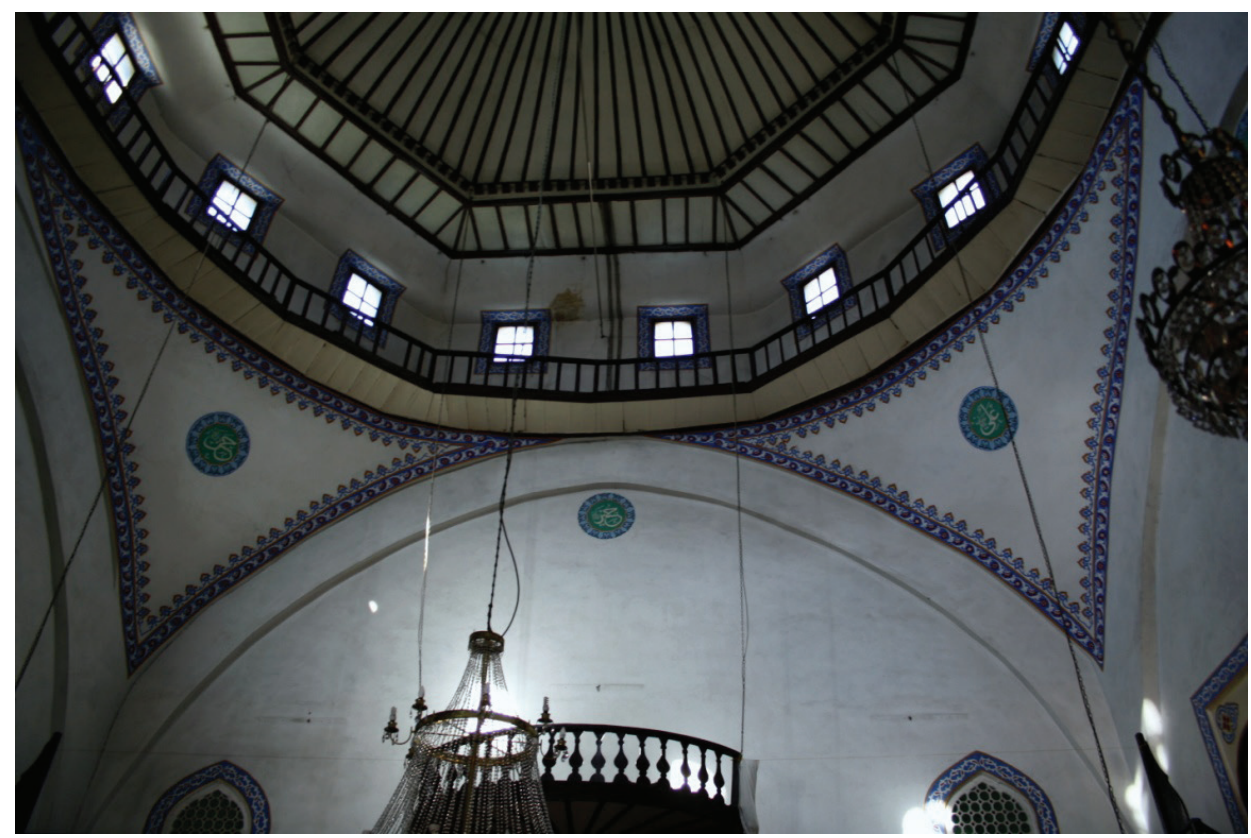

G. 2: Caminin günümüzdeki üst örtüsü (F. Koçyiğit, 2020)

Kare planlı harimin doğu ve batısında birer adet dikdörtgen planlı mekân bulunmaktadır. Bursa kemerli birer kapı ile geçişin yapıldığı bu mekânlar, üç bölümlü ve iki katlıdır (G. 4, G. 5). Harimin kuzeyinde ahşap direkler tarafindan taşınan ve yine ahşap malzeme ile yapılıış kadınlar mahfili bulunmaktadır. Mahfilin orta kısmında, yarım daire şeklinde tasarlanmış çıkması vardır. Bu cephede, altta ve üstte ikişer adet olmak üzere toplamda dört adet pencere bulunmaktadır (G. 6). Güneyde yer alan mihrap, mukarnas kavsaralı olup yarım daire niş şeklindedir. Mihrap nişinin iki yanında birer adet sütunce yer almaktadır. Caminin ahşaptan minberi orijinal değildir (G. 3).

16 V.G.M. 1986: 05.00 / 15 numaralı dosya. 


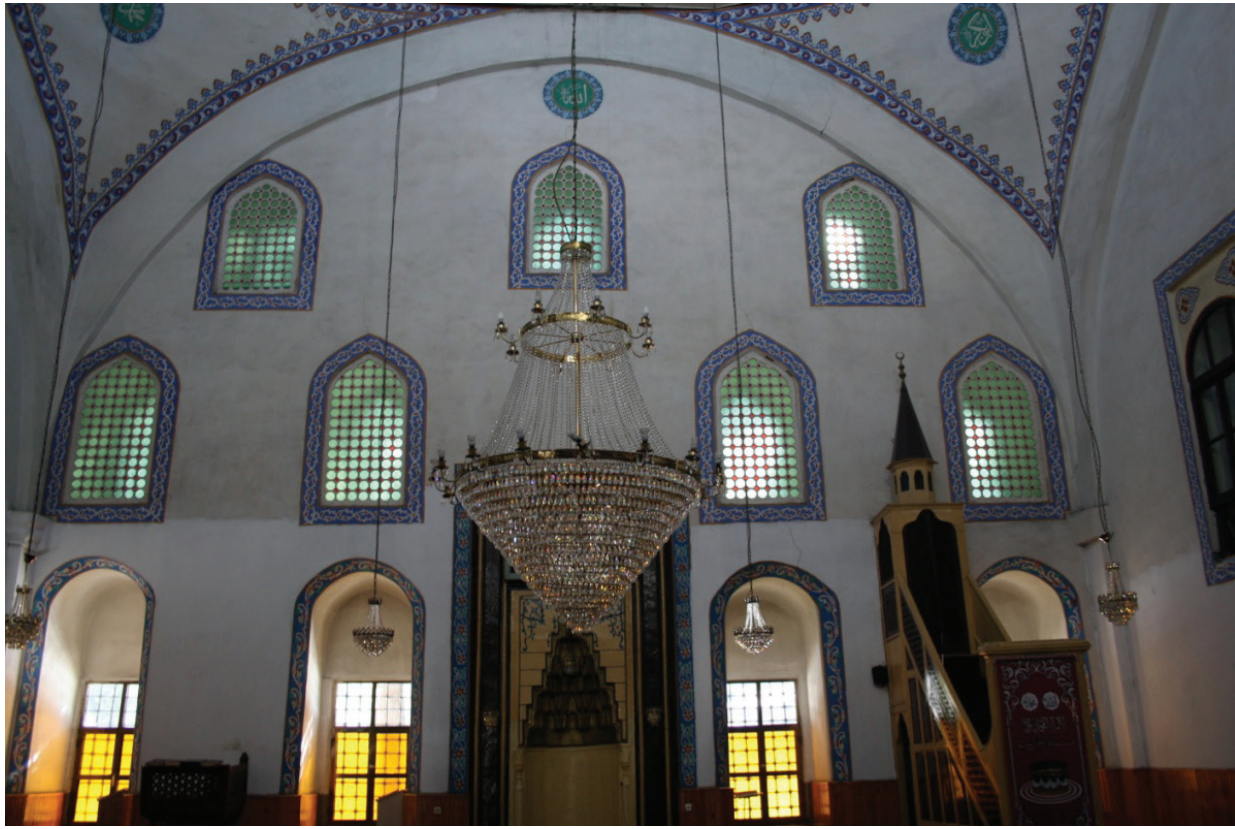

G. 3: Caminin mihrabı ve günümüzdeki bezemeleri (F. Koçyiğit, 2020)

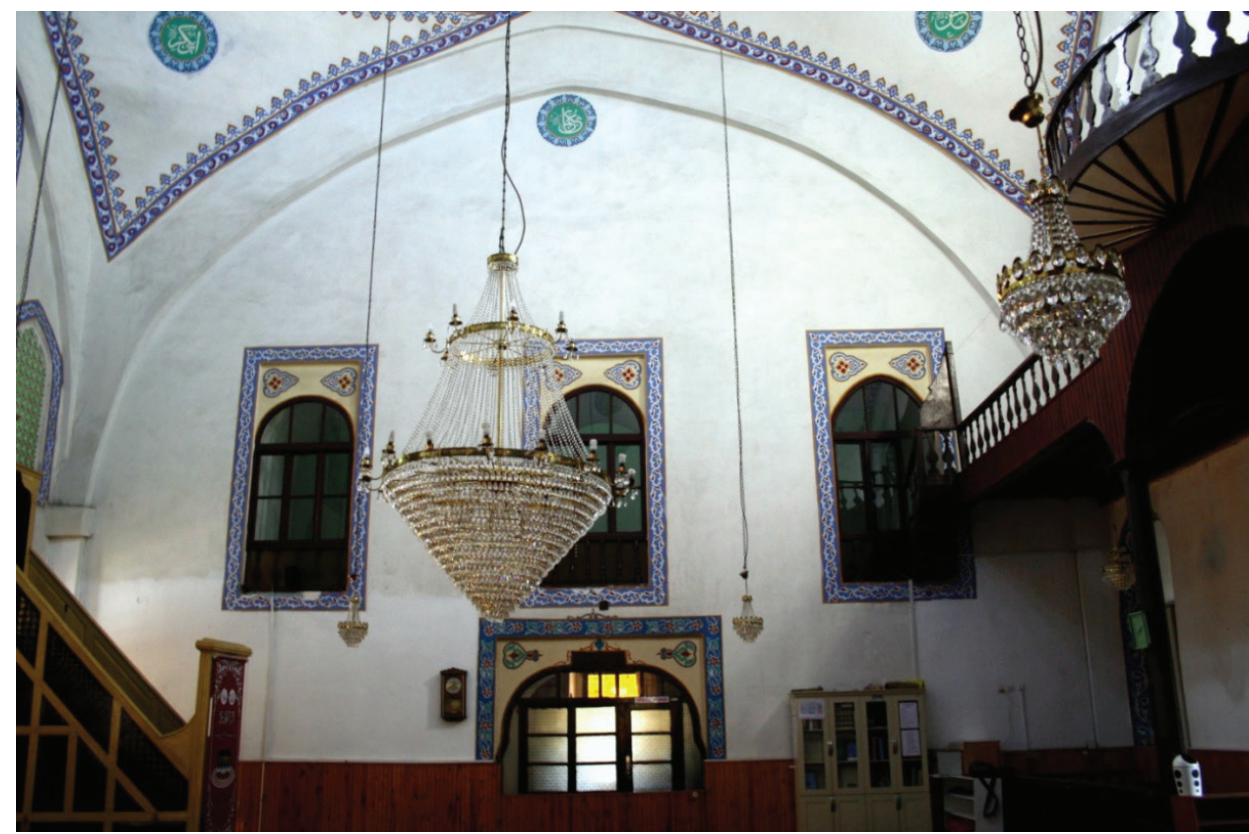

G. 4: Caminin batı tabhane girişi ve günümüzdeki bezemeleri (F. Koçyiğit, 2020) 


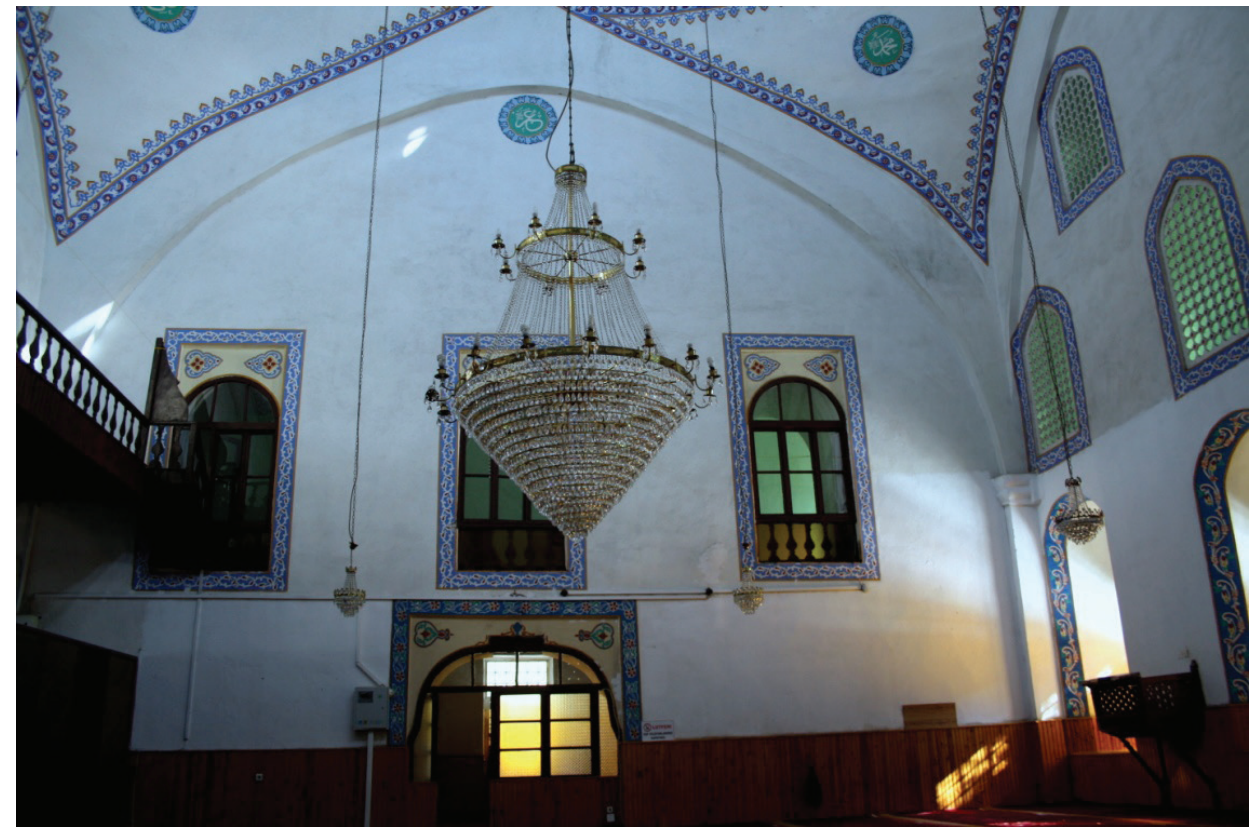

G. 5: Caminin doğu tabhane girişi ve günümüzdeki bezemeleri (F. Koçyiğit, 2020)

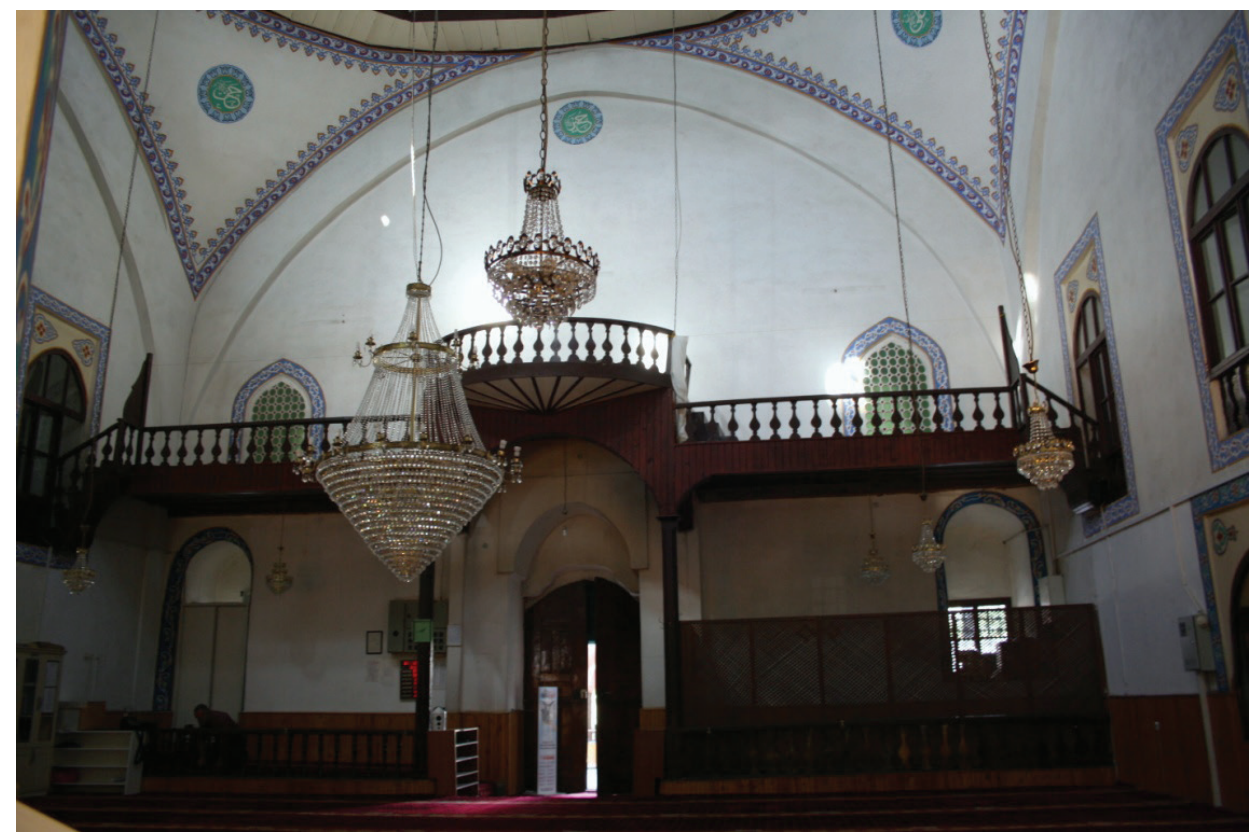

G. 6: Caminin kadınlar mahfili ve günümüzdeki bezemeleri (F. Koçyiğit, 2020)

Caminin kuzeyinde yer alan mukarnas kavsaralı taç kapı, cepheden taşırılmış ve etrafı iç/dış bükey silmelerle çevrelenmiştir. Kapının iki yanında birer adet sütunce 
ve mukarnas kavsaralı yarım daire formunda mihrabiyeleri bulunmaktadır. Sonraki dönem onarımlarında üzeri beyaz yağlı boya ile boyanan taç kapının kavsarası üzerine son cemaat mahallinin kubbesi oturtulmuştur (G. 7, G. 8). 1903 yılına ait olan bu son cemaat mahalli ahşaptan yapılmış olup altı adet ahşap direkle beş bölüme ayrılmıştır. Bu mekânın üzeri ortada ahşap çatkılı bir kubbe, yanlarda ise düz ahşap tavanla örtülmüştür. Son cemaat mahallinin doğusunda bulunan kaş kemerli kapı ile kadınlar mahfiline, batısında bulunan kaş kemerli kapı ile de caminin hem minaresine çıkılmakta hem de batıda bulunan mekâna girilmektedir. Son cemaat mahallinin doğusunda tuğla malzeme ile sonradan yapılmış olan sivri kemerli, kirpi saçaklı küçük bir çeşme bulunmaktadır.

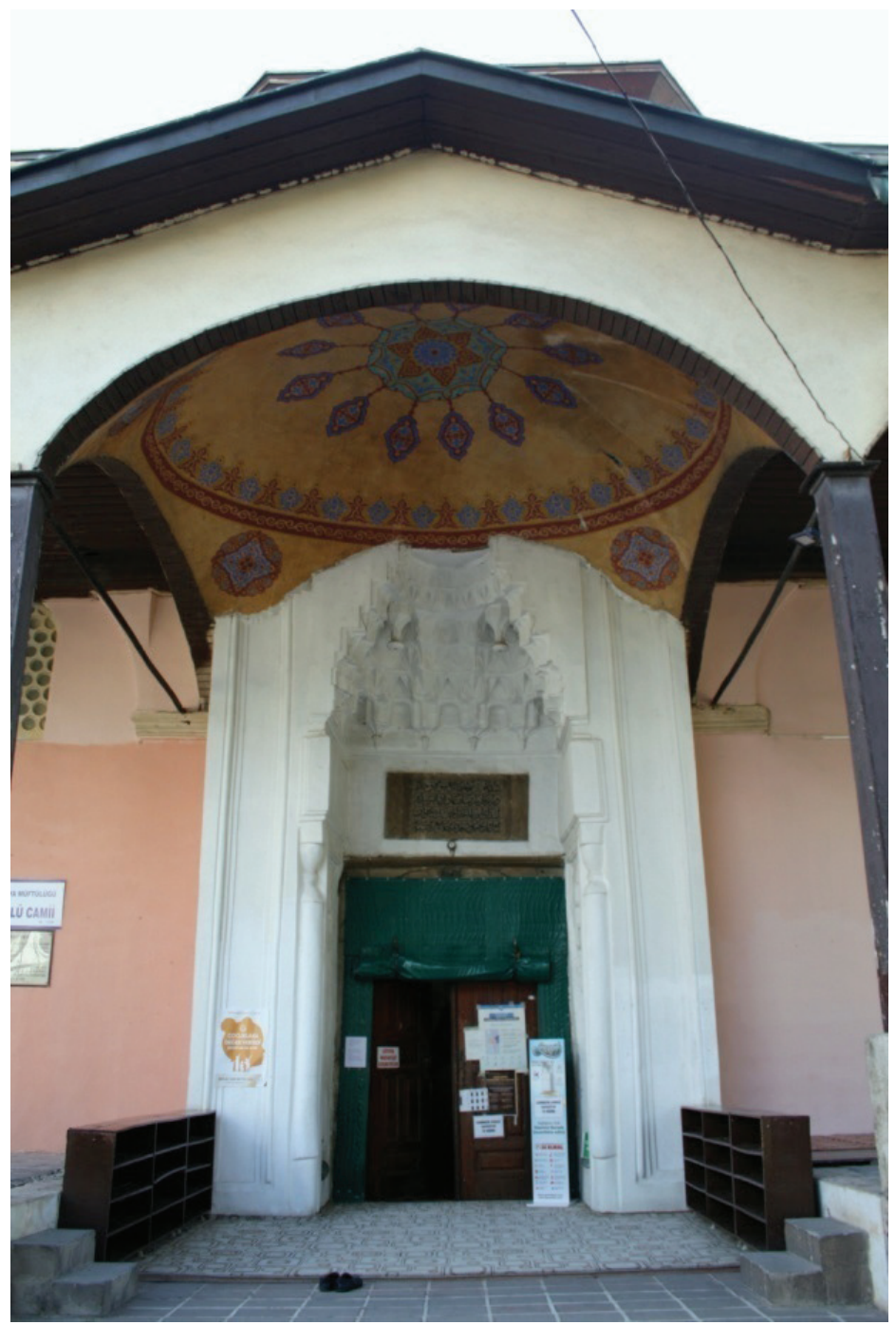

G. 7: Caminin taç kapısı (F. Koçyiğit, 2020) 


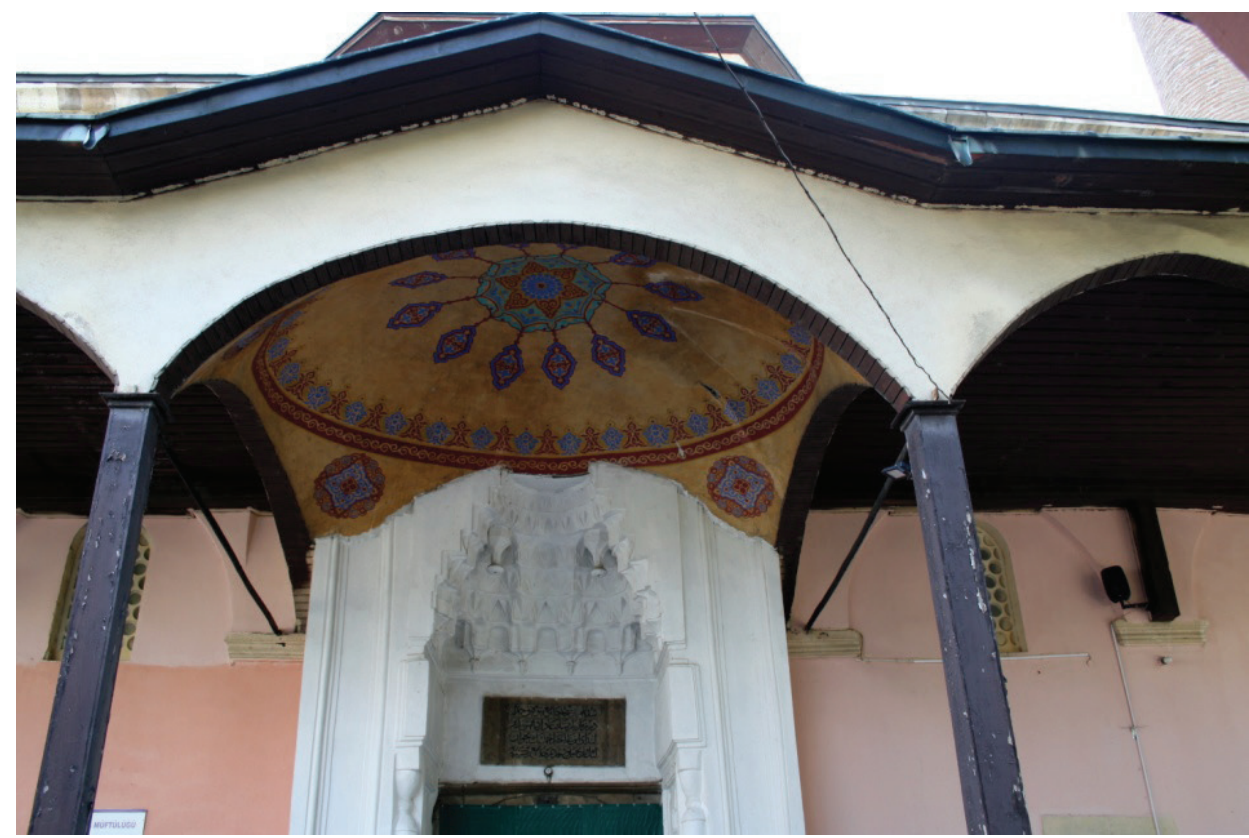

G. 8: Taç kapı üzerine hatalı bir şekilde yerleştirilen orta kubbe (F. Koçyiğit, 2020)

Camide aydınlatma beden duvarlarına ve külah kasnağına açılan pencerelerle sağlanmaktadır. Külah kasnağında her bir yüzeyde ikişer adet olmak üzere toplamda on altı adet pencere vardır. Caminin güney cephesinde on iki adet pencere ile bir adet basık kemerli kapı, kuzey cephesinde dört adet pencere ile kaş kemerli iki adet kapı, batı ve doğu cephelerinde ise beş adet pencere bulunmaktadır. Bu pencereler sivri kemerli ve lentolu olmak üzere iki ayrı formda tasarlanmıştır. Lentolu pencerelerin sağır sivri kemerli alınlıkları vardır.

Yapının kuzeybatısında yer alan tek minaresi, kare kaideli, silindirik gövdeli ve tek şerefelidir. Şerefe altı kirpi dekorlu unsurlarla geçilmiştir. Minarenin kaidesi kesme taştan, gövdesi tuğladandır. Minarenin üzeri alemli bir külahla örtülmüş̧ür.

Caminin avlusunda yer alan sekizgen şadırvanının camiden sonra yapıldığ 1 düşünülmektedir (G. 9). Amasya Müze Müdürlüğü’ne yazılan 1985 tarihli belgede, caminin etrafında İmar İşleri Müdürlüğü tarafından çevre düzenlemesi için yapılan tetkikler sonrasında; caminin Korunması Gerekli Taşınmaz Kültür Varlığı olarak tescilli olmasına karşın şadırvanın tescilli olmadığı ama caminin koruma alanı içerisinde yer aldığı belirtilmiştir ${ }^{17}$. 


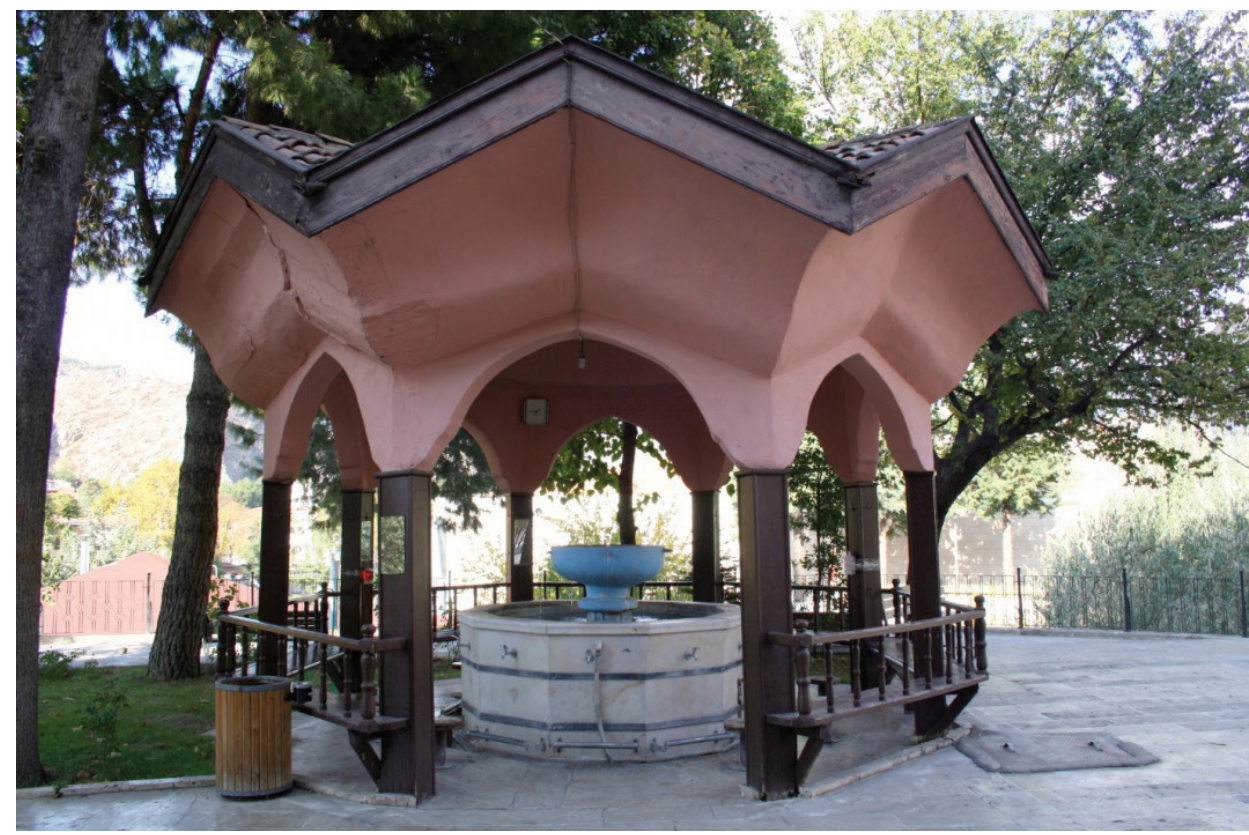

G. 9: Caminin şadırvanı (F. Koçyiğit, 2020)

\section{Yapının Bezeme Programı ve Bezeme Öğeleri}

Kalemişi ve taş bezemenin bulunduğu yapıda bezeme ögeleri, harim kısmında mihrap, pencere söveleri, pandantifler, kemer sırtı ve köşelerinde; harim dışında ise taç kapı, son cemaat mahalli kubbesi ve minarede yoğunlaşmıştır. Kalemişi bitkisel motiflerin bulunduğu camide, mukarnas kavsaralı mihrabın kavsara köşelikleri mavi renkli kıvrım dallar ve stilize çiçek motifleriyle bezenmiştir. Mihrap nişi ve kavsarası sütlü kahve tonunda yağlı boyayla; mihrabı çevreleyen düz silmeler koyu kahverengiye boyanmıştır. Mihrap en dış kısımda, mavi zemin üzerine kırmızı çiçekli ve yeşil yapraklı bitkisel motiflerin yer aldığı bir şerit ile çevrelenmiştir. Mihrabın iki yanında yer alan yuvarlak kemerli pencerelerin etrafını çevreleyen şerit, mavi zemin üzerinde "S ve C" kıvrımları yapan beyaz renkli dallar, sarı ve kırmızı renkli çiçekleri ile yeşil renkli yaprakların birbirini takip etmesiyle oluşturulmuş motiflerle bezenmiştir. Üst kısımda yer alan pencereleri çevreleyen şeride ise mavi zemin üzerine beyaz renkli kıvrım dallar ve kırmızı renkli çiçek motifleri tasvir edilmiştir ancak, burada diğerinden farklı olarak kıvrım dallar sarmal şekilde ilerlemiştir. Tüm pencerelerin üstünde ve orta kısımda madalyon içerisinde hatla yazılmış “Allah” ibaresi bulunmaktadır. Madalyonun orta kısmı yeşil renkli, çerçevesi ise mavi renklidir ve çerçevesi üzerinde stilize lale motifleri yer almaktadır.

Kubbeye geçişi sağlayan pandantiflerin etrafı, mavi zemin üzerine beyaz renkli kıvrım dallar ile kırmızı renkli çiçeklerle ve onun üstünde yer alan palmet dizileriy- 
le iki şerit hâlinde çevrelenmiştir. Pandantiflerin merkezine; orta kısmı yeşil renkli, çerçevesi ise mavi renkli olan ve çerçevesi üzerinde stilize lale motifleri bulunan madalyonlar yapılmıştır. Bu madalyonlarda ise İslam dininin önemli şahsiyetlerinden olan "Muhammed", "Ebubekir", "Hasan" ve "Ali" isimleri yazmaktadır.

Harimin batısında yer alan Bursa kemerli girişin etrafı mavi zemin üzerine beyaz renkli kıvrım dalların, yeşil yaprakların ve kırmızı renkli çiçeklerin nakşedildiği bir şeritle süslenmiştir. Kemer köşelerine de stilize bitkisel motifler işlenmiştir. Girişin üzerinde yer alan yuvarlak kemerli üç adet pencere de aynı şekilde bezenmiş̧ir. Pencerelerin üst kısmında, ortada yer alan madalyonda "Osman" ismi yazmaktadır. Harimin batı cephesi, doğu cephesiyle aynı düzenleme ve bezeme öğelerine sahiptir ancak burada farklı olarak, pencerelerin üst kısmında yer alan madalyon içerisinde "Ömer" ismi yazmaktadır.

Kadınlar mahfilinin bulunduğu cephede, altta ve üstte ikişer adet olmak üzere toplamda dört adet pencere bulunmaktadır. Alttaki pencerelerin yuvarlak kemerli nişlerinin etrafı, mavi zemin üzerine yapılmış beyaz renkli kıvrım dallar ve kırmızı renkli çiçek motifleriyle bezenmiş şeritlerle çevrelenmiştir. Üstte yer alan pencereler ise mavi zemin üzerine beyaz renkli kıvrım dallar ve kırmızı renkli çiçek motifleriyle bezenmiştir ancak burada diğerinden farklı olarak kıvrım dallar sarmal şekilde ilerlemektedir. Pencerelerin üst kısmında, ortada yer alan madalyonda "Hüseyin" ismi yazmaktadır.

Harimin üstünü örten külahın sekizgen kasnağının her bir yüzeyinde ikişer adet, kare formlu pencere yer almaktadır. Bu pencerelerin her biri, mavi zemin üzerine beyaz renkli sarmal şekilde ilerleyen kıvrım dallar ve kırmızı renkli çiçek motifleriyle bezenmiş şeritlerle çevrelenmiştir.

Caminin beş adet ahşap direkle taşınan, dört bölümlü son cemaat mahallinin orta kısmı ahşap bir kubbe ile örtülmüş olup bu kısım üçgen alınlıklı yapılmıştır. Sonraki dönem onarımlarında yapılmış olan bu mahallin kubbesi, hatalı bir şekilde taç kapının kavsarası üzerine oturtularak kavsaranın tepe noktasına büyük oranda zarar verilmiştir. Kubbe, sarı zemin üzerine mavi ve kırmızı renklere boyanmış stilize bitkisel motiflerle bezenmiştir. Kubbenin göbeğinde altı yapraklı bir çiçek motifi, eteğinde ise palmet motifleri yer almaktadır. Kubbe eteğini çevreleyen kırmızı renkli şeridin üzerinde birbirine bağlı şekilde ilerleyen kıvrım dallar bulunmaktadır. Kubbeye geçişi sağlayan pandantiflerin her biri üzerine, merkezinde dört yapraklı stilize bir çiçek formunun yer aldığı ve etrafı kıvrım dallar ile çevrelenmiş madalyonlar yapılmıştır.

Caminin, beyaz yağlı boya ile boyanmış mukarnas kavsaralı bir taç kapısı vardır. Kavsaranın iç kısmında iki adet sarkıt bulunmaktadır. Taç kapının iki yanında, kum 
saati başlıklı birer adet pilastr ve mukarnas kavsaralı mihrabiyeler yer almaktadır. Kavsaranın hemen alt kısmına sülüs hat ile yazılmış inşa kitabesi yerleştirilmiştir. Taç kapı, üç yönden düz ve yarım daire formundaki silmelerle çevrelenmiştir.

\section{Değerlendirme}

Osmanlı Devleti'nin Amasya'da inşa ettirdiği en erken tarihli cami olan Gümüşlü Cami, bu uzun geçmişi içerisinde birçok büyük onarım görerek özgün hâlinden uzaklaşmıştır. Yerel tarihçi H. Hüsameddin'in verdiği bilgiler ışığında yapının ilk inşasında ahşap malzemenin kullanıldığı, sonra çıkan bir yangınla yok olan bu ahşap caminin yerine günümüzdeki kâgir yapının yapıldı̆̆g bilinmektedir. Ancak günümüze gelen bu kâgir yapının da geçirdiği büyük onarımlar sebebiyle cevaplanması gereken bazı sorular ortaya çıkmaktadır. Bu sorulardan birincisi, Gümüşlü Cami, zaviyeli bir cami midir?

Semavi Eyice, zaviyeli camilerin ana şemasının aynı aks üzerinde birbirini takip eden ve üzeri kubbe ya da tonozla örtülü iki ayrı mekân ve bu mekânlardan cümle kapısı tarafında olanlarına bitişik yine kubbeli küçük hücrelerden meydana geldiğini belirtmiştir. Geç dönem örneklerinde ise büyük kubbeli mekânlardan birincisinden vazgeçilmeye başlandığını ifade etmiştir. Bunlara ek olarak ibadet mekânının en az iki basamaklı merdivenle yükseltildiğini, ilk mekânın kubbesinin üzerinde aydınl1k fenerinin bulunduğunu ve burada bir şadırvanın yer aldığını, yan hücrelerin bu mekâna açıldığını ancak geç dönemlerde bu mekândaki şadırvan ile aydınlık fenerinin kaldırılarak ibadet mekânına dâhil edildiğini vurgulamıştır. Doğrudan ibadet mekânı ile bağlantısı olmayan bu yan hücreler ise ibadet etme amaçlı değil, içerisinde bulunan dolaplar ve ocaklardan da anlaşılacağı üzere iskân amaçlı yapılmışlardır. Ancak burada iskân edenlerin belli bir görevi bulunmaktadır. Bu hücreler tabhane olarak adlandırılmıştır ${ }^{18}$.

Tabhaneli camiler olarak da bilinen zaviyeli camiler, Osmanlı Devleti'nde sosyokültürel yapının gereksinimleri doğrultusunda 14. yüzyılda sıklıkla inşa edilmiş, 15. yüzyılın ortalarına kadar da bu camiler yapılmaya devam etmiş̧ir. Ahiler ve gezici dervişler için yapılan bu yapılar; avlu, ibadet mekânı ve tabhane (misafirhane) olarak tanımlanan ana birimlerden meydana gelmektedir. Erken örnekleri genellikle iç avlulu yapılan zaviyeli camilerin, 15. yüzyıl örneklerinde avlu mekânının ortadan kalktığı görülmektedir. Bu yüzyılda avlunun ortadan kalkmasıyla birlikte, tabhane mekânlarına giriş, caminin dışından veya son cemaat mahallinden sağlanmaya başlamıştır ${ }^{19}$. İstanbul Davut Paşa (1485), Tokat Hatuniye (1485), Amasya Mehmed Paşa

18 Semavi Eyice, “İlk Osmanlı Devrinin Dini ve İçtimai bir Müessesi: Zaviyeler ve Zaviyeli Camiler”, İstanbul Üniversitesi İktisat Fakültesi Mecmuasi 1 (1962), 5-9.

19 Türkan Acar, "Tabhaneli Camilerin Tipolojisi Üzerine Bir Deneme”, Süleyman Demirel Üniversitesi, FenEdebiyat Fakültesi Sosyal Bilimler Dergisi 28 (2013), 304-306. 
(1486), Vezirköprü Taceddin Paşa (15. Yüzyıl sonları) ve Edirne II. Beyazıd Camileri (1487-88) avlusuz zaviyeli camilere örnek olarak gösterilebilir ${ }^{20}$.

Gümüşlü Cami, 14. yüzyılda inşa edilmiş bir cami olmasına karşın geçirdiği büyük çaplı onarımlardan dolayı sonraki yüzyıl özelliklerini de göstermektedir. Caminin doğu ve batısında bursa kemerli birer eyvanın iki tarafında yer alan tabhane odaları bulunmaktadır. Bu odalara giriş hem eyvanın içinden hem de dişarıdan sağlanmaktadır. Doğu cephede yer alan tabhane odalarından kuzeyde olanına giriş, son cemaat mahallinde bulunan kaş kemerli küçük bir kapı ile sağlanırken; güneyde olanına, d1şarıdan açılan basık yuvarlak kemerli küçük bir kapı ile eyvan içerisindeki bir kapıdan girilmektedir. Batı cephede yer alan tabhane odalarından kuzeyde olanına giriş, yine son cemaat mahallinden sağlanırken; güneyde olanına eyvanın içinden giriş yapılabilmektedir. Günümüzde bu odaların üstüne ikinci bir kat daha ilave edilmiştir. Bahsi geçen bu ikinci katın 1986 yılı onarımlarından önce yapılmış olması muhtemeldir. Elde ettiğimiz raporlara göre, 1986 yılındaki onarımlarda doğu ve batı cephelerinin yeniden yapıldığ 1 tespit edilmiştir. V.G.M'den alınan 1979 tarihli rölöve çizimlerinde ve fotoğraflarda da görüleceği üzere doğu ve batı cephelerde yer alan tabhane odalarının üst kısmı eğimli bir çatıyla örtülmüş ve bu çatı, harim kısmı üst örtüsünden alt seviyede yapılarak cephede iki katlı bir hareketlilik sağlanmıştır (G.10, G. 11, G. 13). Ayrıca çatının üzerinden yükselen büyük bir sağır sivri kemer de bulunmaktadır. Günümüzde ise bu cephelerin harim üst örtüsü seviyesine kadar yükseltildiği, cephedeki iki katlı hareketliliğin yok edildiği ve buna ek olarak sağır sivri kemerin de yeniden yapılmadığ 1 görülmektedir. Bunun dışında, bahsi geçen çizim ve fotoğraflardan elde ettiğimiz verilere göre bu tarihlerde son cemaat mahallinin yan tarafları, kâgir malzeme ile kapatılmıştır. Son cemaat mahallinin ahşap olduğu göz önüne alındığında buranın sonraki dönem onarımlarında kapatıldığı söylenebilir. Günümüzde bu kısımların açık bırakılması da bu iddiayı destekler niteliktedir.

20 Türkan Acar, "Tabhaneli Camilerin Tipolojisi Üzerine Bir Deneme”, 309-310. 


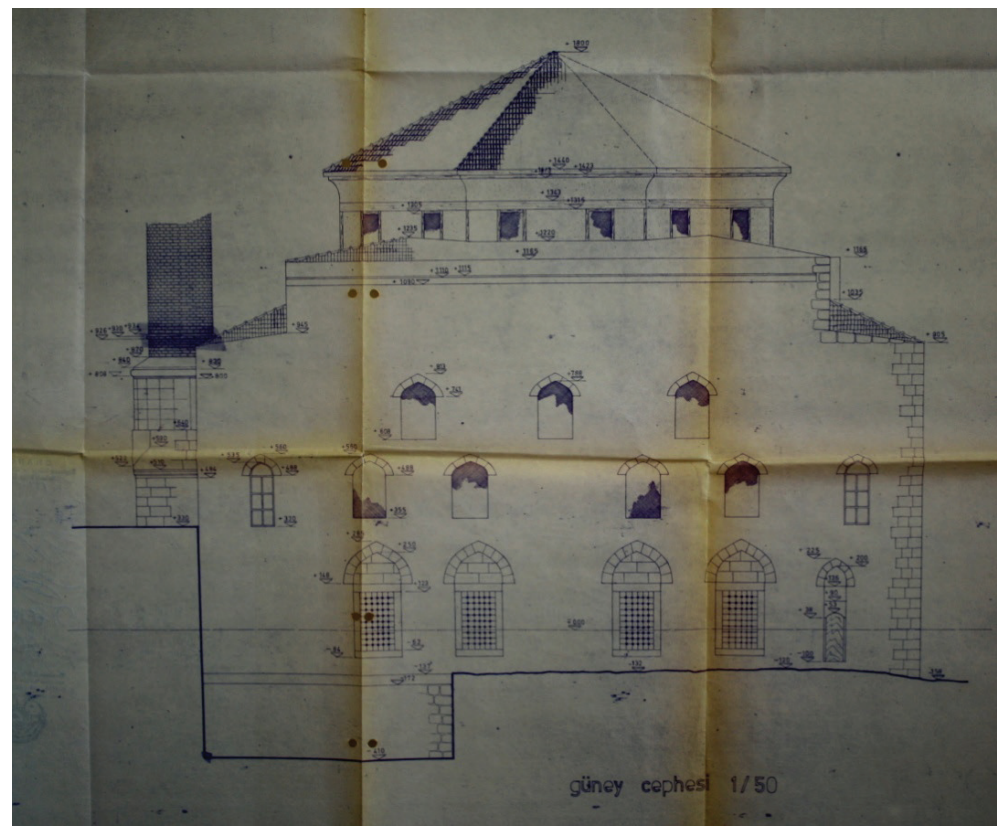

G. 10: Caminin 1979 tarihli güney cephe rölövesi (Samsun Vakıflar Bölge Müdürlüğü)

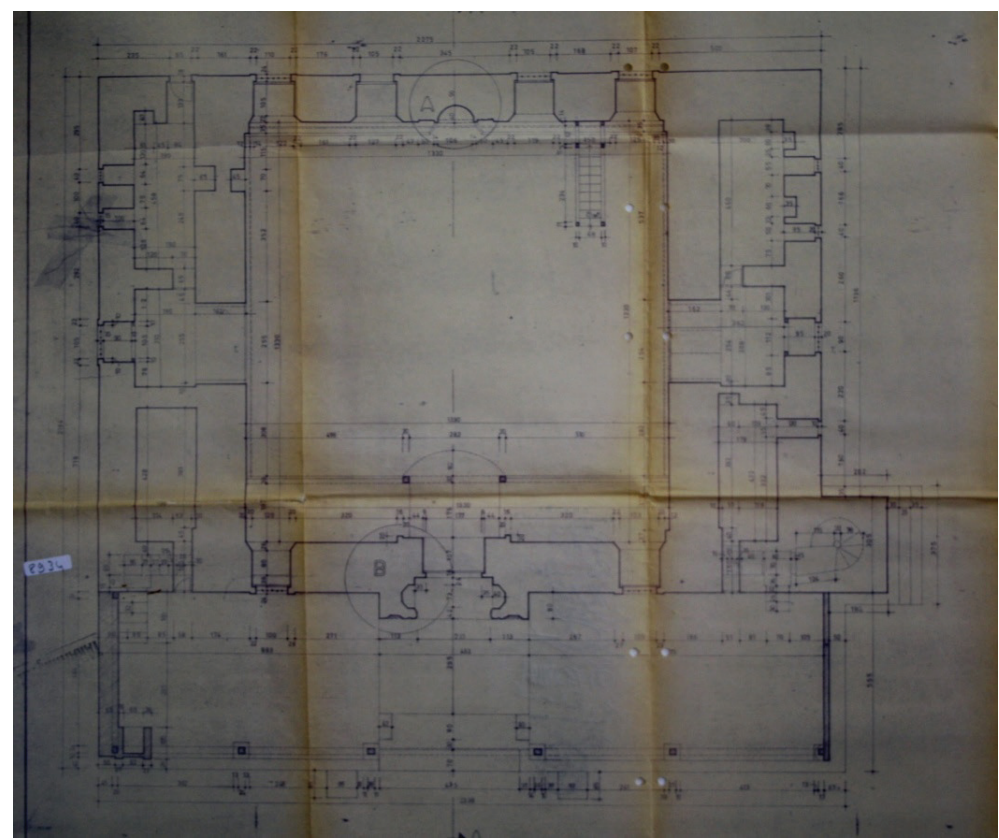

G. 11: Caminin 1979 tarihli rölövesi (Samsun Vakıflar Bölge Müdürlüğü) 


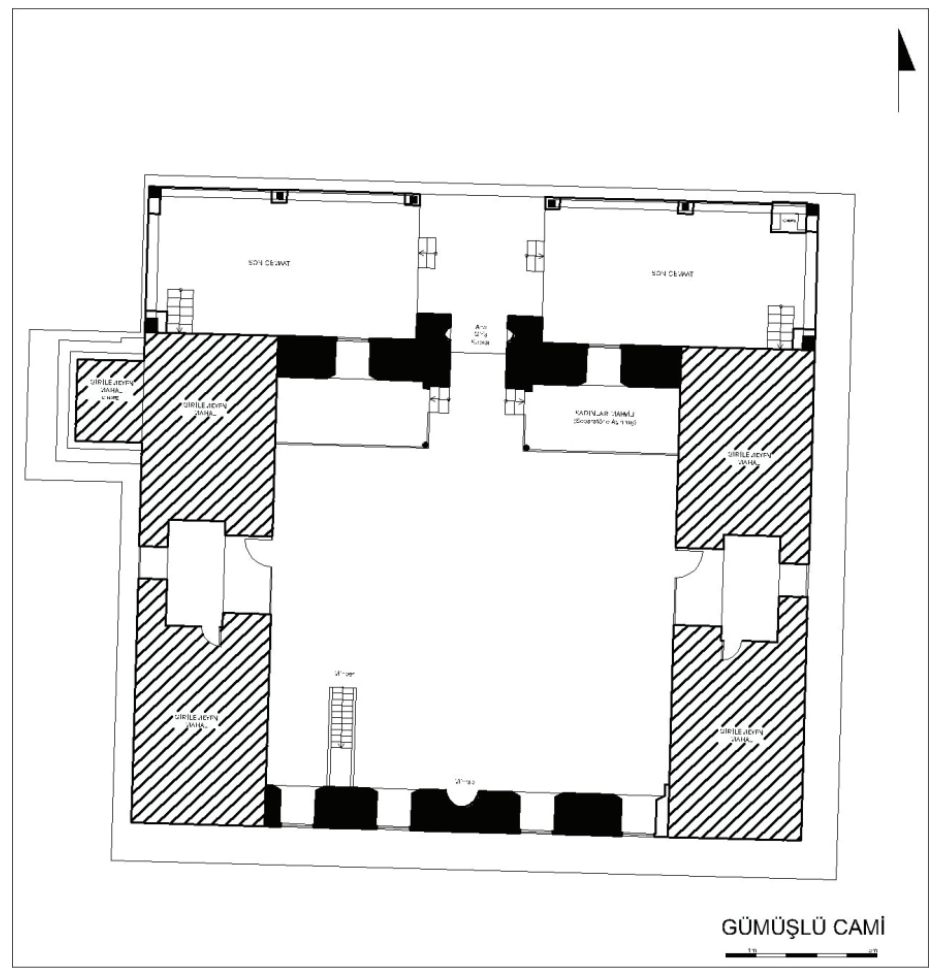

G.1 2: Caminin Şematik Rölövesi(F. Koçyiğit, 2020)

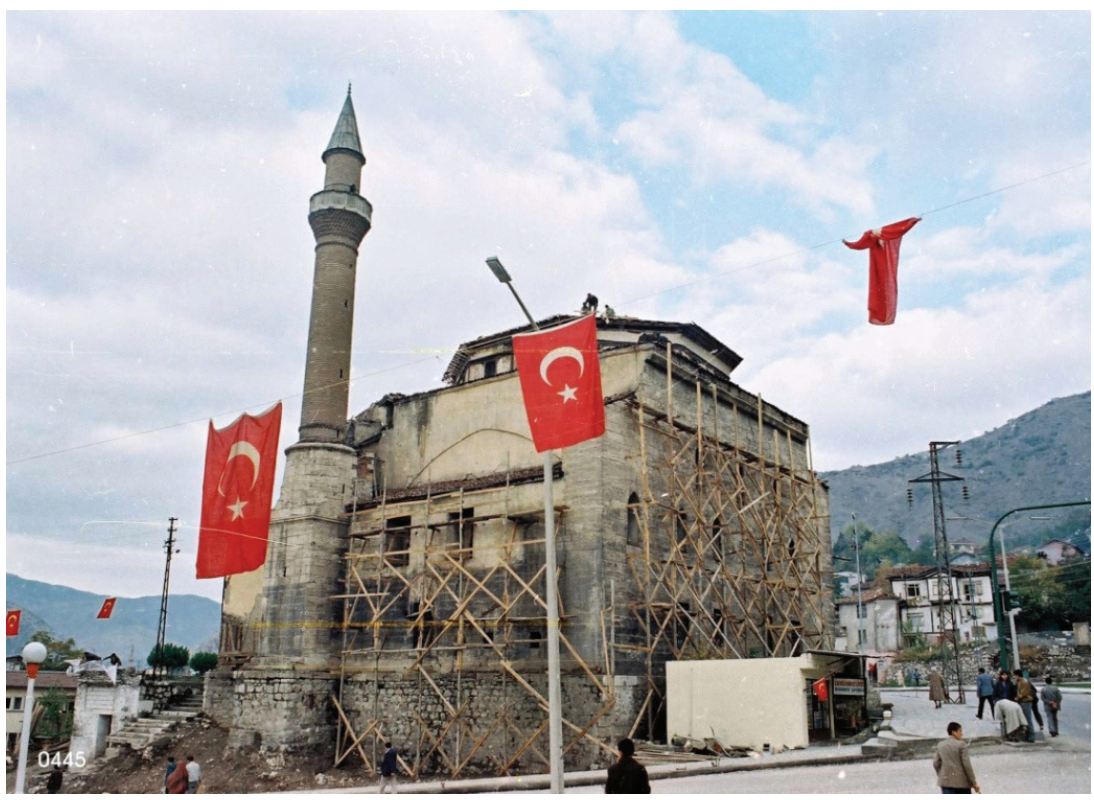

G. 13: Camiye ait eski fotoğraf, tabhane odalarının dışarıdan görünüşü (Samsun Vakıflar Bölge Müdürlüğü) 
Caminin günümüzdeki ahşap karkaslı son cemaat mahalli, 1903 yılında yapılmıştır. Hatalı bir şekilde taç kapı kavsarasına oturtulan orta kubbe, taç kapıya büyük oranda zarar vermiştir (G. 14). Bu mahallin özgün hâlinde nasıl olduğuna dair herhangi bir veriye ulaşılamamıştır ancak yapının kâgir malzeme ile inşa edilmiş olması ve 15 . yüzyılda Amasya' da yapılmış olan Mehmed Paşa (M 1486) ${ }^{21}$ ve Beyazıd Paşa (M $1414)^{22}$ zaviyeli camileri göz önüne alınırsa son cemaat mahallinin özgün hâlinde kâgir malzeme ile inşa edildiği iddia edilebilir. Son cemaat mahallinin kuzey cephede yer alan sağır yuvarlak kemerleri, yastıkları ve taç kapı kavsarasını kesmesi, bu mahallin özgün hâlinde daha yüksek yapıldığını ve bu mahallin kubbeli bir üst örtüsü olduğunu düşündürmektedir. Eski fotoğraflarda görüldüğü üzere taç kapının hemen batısında bulunan müezzin mahfili, günümüzde pencere olarak kullanılmaktadır.

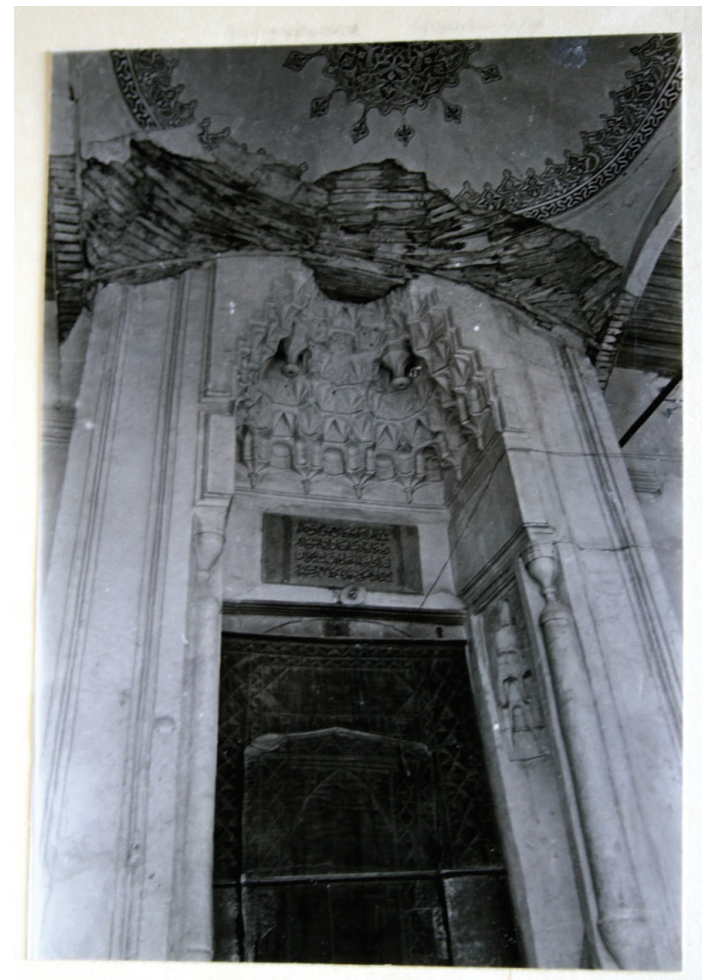

G. 14: Camiye ait eski fotoğraf, orta kubbe ve taç kapı (Samsun Vakıflar Bölge Müdürlüğü)

Yapının özgün üst örtüsüne dair herhangi bir bilgiye ulaşılamamıştır. Günümüzde sekizgen kasnak üzerine ahşap karkaslı bir külah yapılmıştır. Osmanlı Devleti’nde erken dönemlerden itibaren üst örtü sisteminin genellikle kubbe olması ve Amasya'da

21 Ebru Karakaya, "Mehmed Paşa Külliyesi”, TDV Íslam Ansiklopedisi, c. 28 (Ankara: Türkiye Diyanet Vakfı Yayınlar1, 2003), 511.

22 Semavi Eyice, “Beyazıd Paşa Cami, Amasya'da XV. Yüzyıl Başlarında Yapılan Cami”, TDV İslam Ansiklopedisi, c. 5 (Ankara: Türkiye Diyanet Vakfı Yayınları, 1992), 243. 
inşa edilmiş diğer erken dönem camileri göz önüne alındığında caminin üst örtüsünün özgün hâlinde kubbe olduğu iddia edilebilir. Günümüzdeki üst örtünün ne zaman yapıldığına dair bir bilgi bulunmamasına karşın, yapım tekniklerinin benzerliğinden yola çıkılarak harim kısmı üst örtüsünün de son cemaat mahalli gibi 1903 yılı onarımlarında yapılmış olabileceği düşünülebilir.

Geçirmiş olduğu büyük onarımlarla özgün şeklini kaybeden Gümüşlü Cami’nin sadece mimarisi değil bezemeleri de sonraki dönem onarımlarında büyük değişikliklere uğramış ve kayıplar yaşamıştır. Caminin harim kısmında yer alan günümüzdeki bezemeleri, 1960 yılı onarımlarında yapılmıştır. Caminin bu onarımlar öncesinde sahip olduğu bezeme programı ve motiflerine dair bilgilere eski fotoğraflardan ulaşılmaktadır. Bu belgelerden yola çıkarak caminin onarımlar öncesindeki bezemelerinin Barok etkili olduğu söylenebilir. Bezeme programı, günümüzdeki programına benzer şekilde mihrap, pencere söveleri, pandantiflerde karşımıza çıkmakla birlikte bugünkünden farklı olarak duvar yüzeylerine ve kasnak pencerelerinin aralarına da çeşitli motiflerin yapıldığı görülmektedir. Caminin özgün bezemelerinden en dikkat çekici olanı ve günümüze ulaşamayanı harim kısmı giriş duvarında yer alan Selimiye Cami tasviridir (G. 15). Bu tasvir, Merzifon Kara Mustafa Paşa Camisi’ndeki Süleymaniye Camisi tasvirine benzemektedir ${ }^{23}$. Günümüze ulaşamayan bu tasvirde cami, dört minareli ve kubbeli yapılmıştır. Ana kubbenin önünde bir de yarım kubbe ile ağırlık kuleleri bulunmaktadır. Tasvir edilen caminin son cemaat mahalli yedi bölümlü olup bu kısım da kubbelerle örtülmüştür. Tasvirde yer alan tüm kubbe ve külahlar mavi renge boyanmıştır. Caminin avlusuna dört ayaklı bir şadırvan ile çeşitli ağaç tasvirleri yapılmıştır.

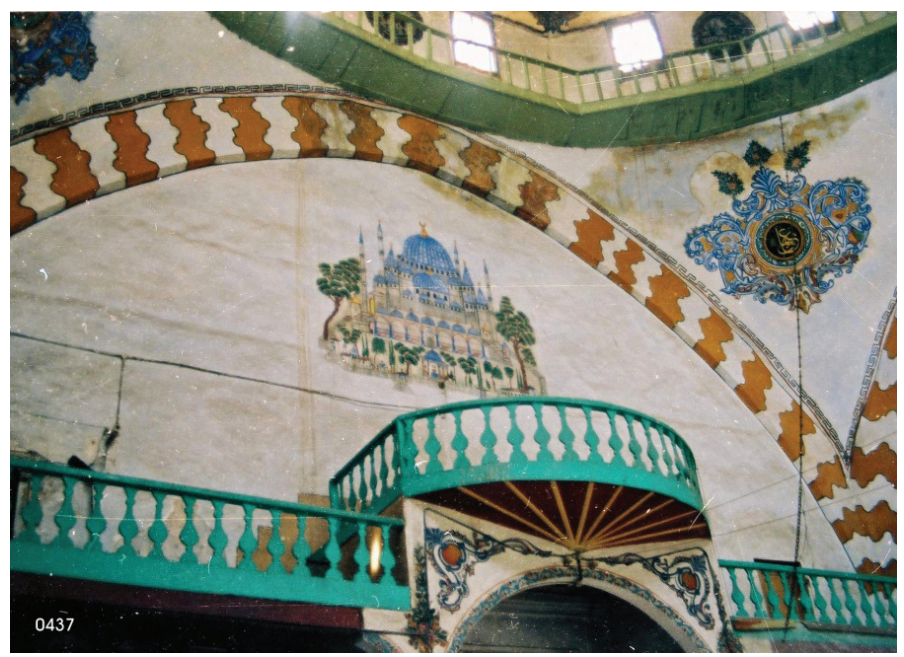

G. 15: Caminin harim kısmında yer alan ve günümüze gelemeyen Selimiye Cami tasviri (Foto Apaydın Arşivi)

23 Rüçhan Arık, "Sanatta Batılılaşma Sürecinde Balkan Anadolu Beraberliği”, Balkanlarda Kültürel Etkileşim ve Türk Mimarisi Sempozyumu Bildirileri, 17-19 Mayıs 2000, Şumnu (Bulgaristan), c. 1, (Ankara: Atatürk Kültür Merkezi Yayınları, 2001), 73. 
Caminin özgün hâlinde, harim kısmında yer alan dört adet ana kemerin birbirine geçmeli şekilde sarı ve beyaz renklerin almaşıklı̆̆ıyla bezendiği görülmektedir. Günümüzde bu kemerlerin üstü sıvanmış ve beyaz renge boyanmıştır. Pandantiflerde yer alan madalyonlar içerisinde yine cihâr-1 yâr-i güzîn isimleri yazmakla birlikte özgün hâlinde madalyonların etrafının "S ve C" kıvrımları yapan kıvrım dallarla bezendiği görülmektedir. Bu kıvrım dallar ve stilize yaprak motifleri mavi, sarı, kırmızı renklere boyanmıştır. Bu motifin tepe noktasında ise üç adet natüralist yeşil renkli yaprak motifleri bulunmaktadır. Bezemelerin özgün hâlinde mihrabın iki yanına birer adet sütunce resmedilmiştir. Üzeri, beş yapraklı çiçek motifi ve yapraklarla bezenen bu sütuncelerin başlıkları üzerinde yükselen kıvrım dallar, mihrabın tepe noktasında birleştirilmiş ve bu birleşme noktasına küçük bir madalyon içerisinde "Allah" yazılmıştır. Mihrabın hemen üzerinde yer alan ve günümüze ulaşamayan ayet kitabesinin etrafi dikdörtgen bir çerçeve şeklinde yaprak ve çiçek motifleriyle bezenmiştir. Mihrabın iki yanında yer alan yuvarlak kemerli pencerelerin söveleri yeşil renkli akantüs yapraklarıyla bezenmiş, yapraklar arasında kalan boşluklar sarı renkle boyanmıştır. Pencereleri dıştan, mavi ve kırmızı renklere boyanmış yaprak dizileri sarmıştır. Bu pencerelerin üstünde yer alan küçük pencerelerin etrafı, mavi zemin üzerine beyaz renkle yapılmış akantüs yapraklarıyla bezenmiştir. Pencerelerin üst kısmına dor stilinde sütun başlıkları tasvir edilmiş ve bu başlıkların üzerinden kıvrım dallar, akantüs yaprakları yükseltilerek tepe noktasında taç görüntüsü elde edilmiştir. Bu pencerelerin üstünde yer alan madalyon içindeki "Allah" ve "Muhammed" yazıları da pandantiflerdeki madalyonlara benzer şekilde kıvrım dallar ve yapraklarla bezenmiştir. En üstte yer alan pencereler ise mavi zemin üzerine yapılmış ve birbirine geçmeler yapan dallarla bezenmiş ve bu dalların köşe noktalarına da birer adet palmet motifi resmedilmiştir. Mihrap duvarında yer alan en üstteki pencerenin üzerine "S" kıvrımlı dallardan çıkan akantüs yapraklarıyla bezeli bir taç yapılmış ve tacın orta kısmına sülüs hatla "Allah" yazılmıştır (G. 15). Caminin özgün bezemelerinde harim kısmında, her pencere ayrı şekilde bezenmiştir ancak bu pencere bezemelerinin ortak özelliği çevrelerinin sarmal ya da geçmeler yapan kıvrım dallarla bezenmiş olması ve pencere üstlerine tasvir edilen taçların kıvrım dallar ve akantüslerle bezenmesidir. Bu pencerelerde Bektaşi ve Mevlevi sembollerinden olan serpuşların da (tac-1 şerif) tasvir edildiği görülmektedir. Merzifon Kara Mustafa Paşa Cami'nin şadırvanındaki kubbede de serpuş tasvirleri yer almaktadır. Zileli Emin Usta'nın imzası bulunan bu eserde Bektaşi ve Mevlevi serpuşlarının resmedildiği bilinmektedir. Gümüşlü Cami'nin günümüze ulaşamayan pencere süslemelerinde yer alan serpuş tasvirlerinin Kara Mustafa Paşa Cami şadırvanındaki serpuş tasvirlerine benzerlik göstermesi de Gümüşlü Cami'deki tasvirlerin Zileli Emin Usta tarafından yapıldığını desteklemektedir ${ }^{24}$. Pencerelerin kemer köşeleri natüralist çiçek motifleri ile süslenmiştir. Pencereler arasında kalan yüzeylere ise şerit şeklinde

24 Baha Tanman, “Merzifon, Kara Mustafa Paşa Camii Şadırvanının Kubbesinde Zileli Emin'in Yarattığı 'Osmanlı Dünyası' ve Bu Dünyaya Yansıyan Kişiliği”, Sanat Tarihinde İkonografik Araştırmalar Güner Inal'a Armağan, (Ankara: Hacettepe Üniversitesi Edebiyat Fakültesi Yayınları, 1993), 495-496. 
stilize edilmiş palmet motifleri yapılarak bağlantı kurulmaya çalışılmıştır. Pencere aralarına yapılan şemse şeklindeki büyük motifler ise natürel çiçek motiflerinin yanı sıra kıvrım dallarla bezenmiştir (G.17, G. 18, G. 19).

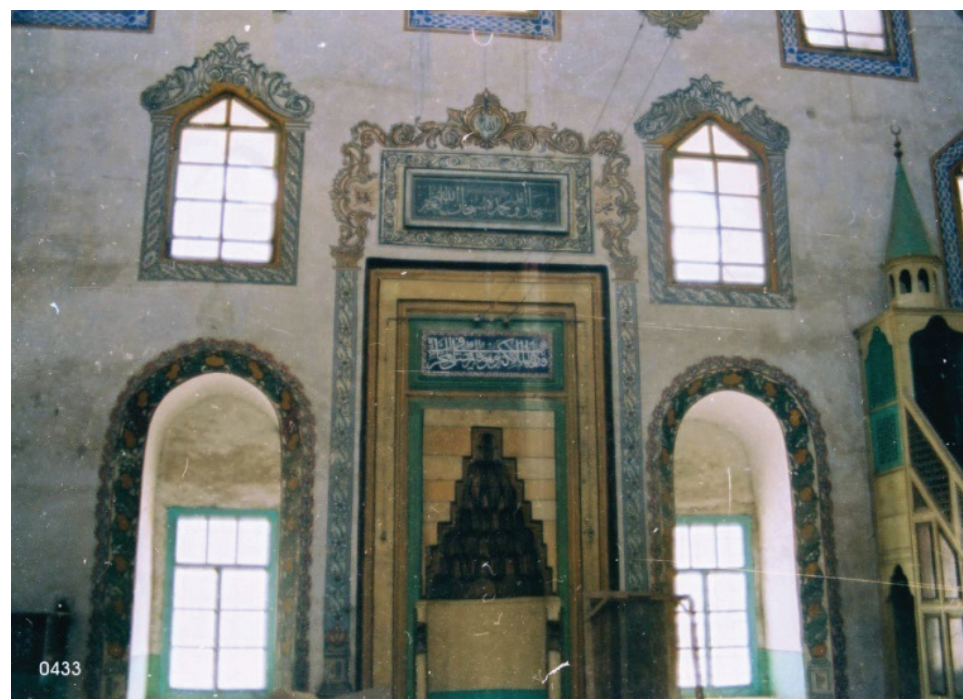

G. 16: Caminin bezemelerine ait eski fotoğraf (Foto Apaydın Arşivi)

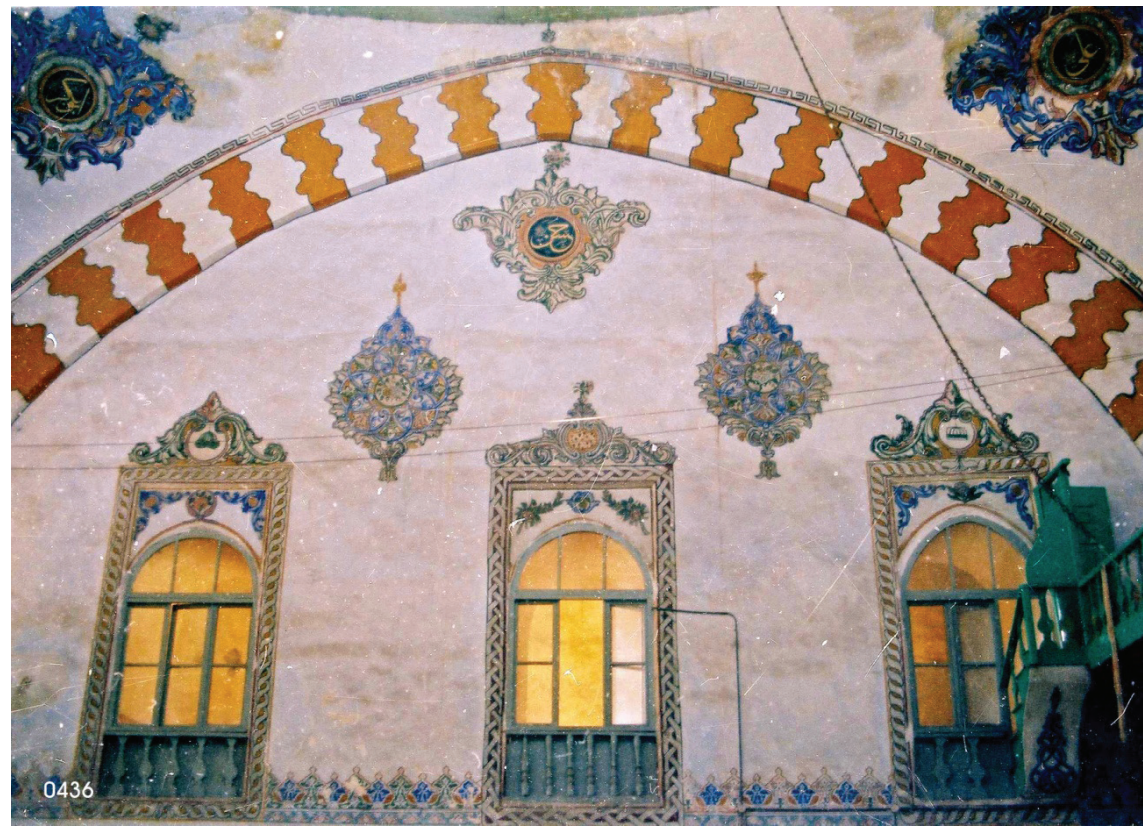

G. 17: Caminin bezemelerine ait eski fotoğraf (Foto Apaydın Arşivi) 


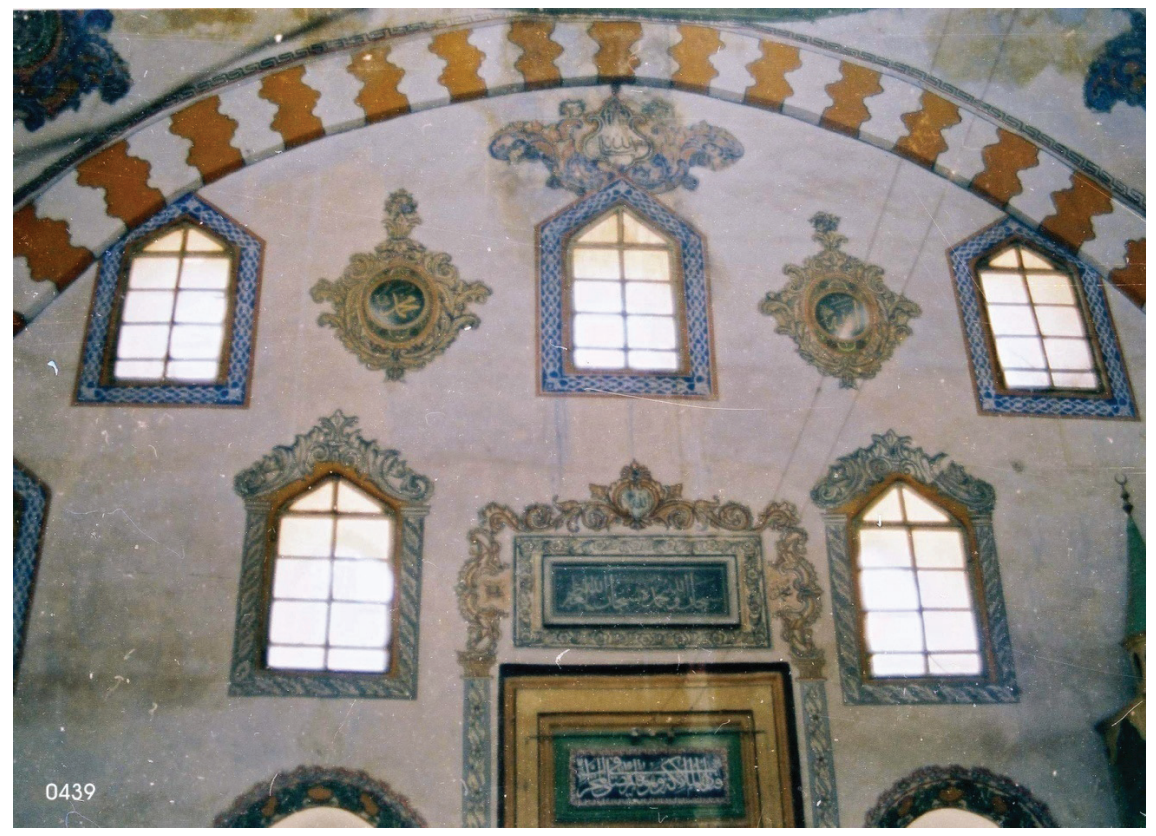

G. 18: Caminin bezemelerine ait eski fotoğraf (Foto Apaydın Arşivi)

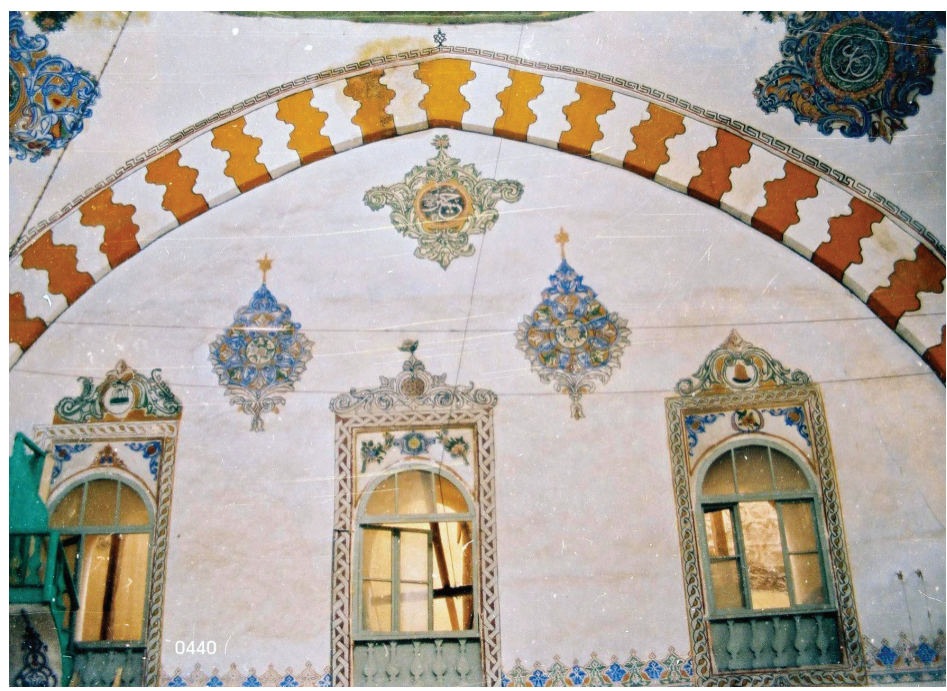

G. 19: Caminin bezemelerine ait eski fotoğraf (Foto Apaydın Arşivi)

Eski fotoğraflardan elde ettiğimiz kısıtlı verilere göre kasnakta pencere aralarına madalyonlar içerisinde manzara tasvirleri yapılmıştır ancak bunların hiçbiri günümüze ulaşmamıştır (G. 20). 


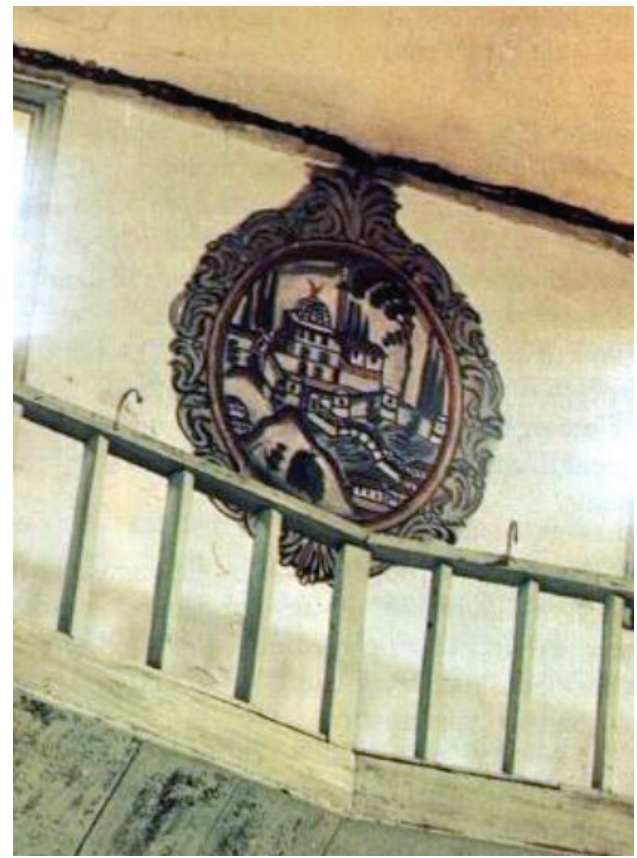

G. 20: Caminin kasnağında yer alan ve günümüze ulaşamayan manzara tasviri (Rüçhan Arık, Batılılaşma Dönemi Anadolu Tasvir Sanatı, 80)

Osmanlı Devleti, 18. ve 19. yüzyıllarda siyasi ve ekonomik sebeplerle Batı'ya açılım yapmış ve bu açılımlar neticesinde Batılılaşma (Yenileşme) Dönemi olarak adlandırılan yeni bir sürece girmiştir. Bu yeni süreçte sadece siyasi anlamda değil sanat alanında da değişimler yaşanmış ve sanatta Barok, Rokoko tarzı görülmeye başlanmıştır ${ }^{25}$. Mimaride kendini daha çok bezeme öğelerinde gösteren bu yeni batılı üsluplar, klasik Osmanlı sanatının geometrik ve bitkisel motiflerinin yerini almakla kalmamış, zamanla duvar yüzeylerine manzara ve natürmort resimleri de yapılmıştır ${ }^{26} .18$. yüzyılın ikinci yarısında ortaya çıkan ve duvar resmi olarak adlandırılan bu yeni üslup başkente özenen ayanlar sayesinde Anadolu'nun her köşesinde görülmüştür ${ }^{27}$. Ayanların yanlarında getirdiği sanatçılardan usta-çırak ilişkisi içinde duvar resmi yapmayı öğrenen halk sanatçıları, kendi yetenekleri ve halkın istekleri doğrultusunda duvar resimleri yapmışlardır. Halk sanatçılarının akademik bir eğitim almamasından ve halkın isteği doğrultusunda hareket etmelerinden dolayı taşrada görülen duvar resimlerinde üslup birliğine rastlanılmamaktadır ${ }^{28}$. Uzun yıllar şehzadeler şehri sıfatına sahip olması sebebiyle Amasya,

25 Günsel Renda, "Yenileşme Döneminde Kültür ve Sanat", Türkler Ansiklopedisi, c. 15 (Ankara: Yeni Türkiye Yayınları, 2002), 265-266.

26 Günsel Renda, Batılılaşma Döneminde Türk Resim Sanatı 1700- 1850 (Ankara: Hacettepe Üniversitesi Yayınları, 1977), 193-194.

27 Rü̧̈han Arık, "Osmanlı Sanatında Duvar Resimleri”, Osmanlı Kültür ve Sanat Ansiklopedisi, c. 11 (Ankara: Yeni Türkiye Yayınları, 1999), 431.

28 Pelin Tekinalp Şahin, "Batılılaşma Dönemi Duvar Resmi”, Türkler Ansiklopedisi, c. 15 (Ankara: Yeni Türkiye Yayınları, 2002), 443-444. 
Osmanlı Devleti zamanında önemli kentlerden biri olma özelliğini korumuş ve birçok devlet adamına ev sahipliği yapmıştır. Devletin ileri gelenleri tarafından mamur edilen kentte, başkente öykünme şeklinde sanatsal icraatların da gerçekleştirildiği görülmektedir. Bu sebepledir ki kent, halk sanatçılarına da kapılarını açmıştır. Bu sanatçılardan en tanınmış olanı, Amasya, Merzifon ve Tokat'ta duvar resimleri yapan ve bunların bir kısmına imzasını atan Zileli Emin'dir. Sanatçının, Sofular Cami (M 1875) ile Merzifon Kara Mustafa Paşa Cami'nin (M 1875) harim ve şadırvan kubbesindeki duvar resimlerini yapmış olduğu eserlerdeki imzasından anlaşılmaktadır. Amasya Sultan II. Beyazıd Cami'nin şadırvanında (M 1872) yer alan duvar resimleri de üslupsal açıdan Merzifon Kara Mustafa Paşa Cami'nin şadırvanındaki duvar resimleriyle büyük benzerlik göstermektedir. Gümüşlü Cami'nin günümüze ulaşamayan duvar resimlerinden olan Selimiye Cami tasviri ile manzara resimleri de Zileli Emin Usta'nın üslubuna benzemektedir ${ }^{29}$. Buna ek olarak Arık, kubbe kasnağında on adet madalyon bulunduğunu, bunların sekizinde manzara, ikisinde natürmort tasvirlerinin yer aldığını belirtmiştir. Madalyonlarda yer alan bu tasvirleri, üslupsal özellikleri açısından Merzifon Kara Mustafa Paşa Cami şadırvanındaki tasvirlere benzeten Arık, manzara resimlerinden bazılarının Amasya'ya ait olduğunu da ifade etmiştir. Caminin günümüze ulaşamayan natürmort bezemeleri içerisinde vazo içinde çiçek, kâse içinde meyve ve dilimli karpuz tasvirlerinin de bulunduğunu söylemiştir ${ }^{30} .18$. yüzyılın ikinci yarısından 19. yüzyılın sonuna kadar uzanan zaman diliminde, Anadolu'nun birçok kentinde benzer bezeme örnekleri karşımıza çıkmaktadır. Bu bezemeler, Barok, Rokoko ve Ampir üslup özelliklerini gösterseler de bezemeyi yapan halk sanatçısının yeteneği ve yorumu doğrultusunda şekillenmişlerdir. Kütahya ili, Tavşanlı ilçesinde bulunan 1871 tarihli Kurşunlu Cami'de Selimiye ve Süleymaniye Camileri tasvir edilmiş olmasına karşın buradaki tasvirlerin, Gümüşlü Cami'deki tasvirlerden farklı olduğu görülmektedir ${ }^{31}$. Yozgat Çapanoğlu (M 1779-1793) ${ }^{32}$ ve Başçavuşoğlu Camileri ${ }^{33}$ de gerek manzara gerekse barok bezemeleri açısından oldukça zengin örnekler olup sanatçı farklılı̆̆ 1 burada da görülmektedir. Tüm bu verilerden yola çıkarak Gümüşlü Cami’nin özgün bezemelerinin 18. ve 19. yüzyıl bezeme anlayışına ve programına uygun şeklide yapıldığı söylenebilir. Caminin bezemelerinin üslupsal özellikleri ise yerel bir sanatçı olan ve Amasya'da birçok esere imzasını atan Zileli Emin Usta'nın üslubuyla benzerlik göstermektedir. Bu sebeple, Arık ve Cantay'ın da belirttiği gibi Gümüşlü Cami'nin

29 Rüçhan Arık, "Sanatta Batılılaşma Sürecinde Balkan Anadolu Beraberliği", 73.

30 Rüçhan Arık, Batılılaşma Dönemi Anadolu Tasvir Sanatt, (Ankara: Türkiye İş Bankası Kültür Yayınları, 1988), 80-83.

31 Nilgün Çöl, "Kütahya İli Tavşanlı İlçesinde Kurşunlu Camiinin Duvar Resimlerinin Geleneksel Türk Duvar Resim Sanatı Çerçevesinde Değerlendirmesi: Osmanlı Sanatı Çerçevesinde Duvar Resmi”, Anadolu Üniversitesi Güzel Sanatlar Fakültesi Anadolu Sanat Dergisi 12 (2002), 61.

32 Enis Karakaya, "Çapanoğlu Camii Yozgat’ta XVIII. Yüzyılda Batı Üslubunda İnşa Edilen Cami”, TDV İslam Ansiklopedisi, c. 8 (Ankara: Türkiye Diyanet Vakfı Yayınları, 1993), 219-220.

33 Oğulcan Avcı, "Yozgat Başçavuşoğlu Camii ve Süslemeleri Üzerine Düşünceler", Osmanlı Mirası Araştırmalart Dergisi 5/3 (2016), 52-55. 
günümüze ulaşamayan özgün duvar resimlerinin 1870'li yıllarda Zileli Emin Usta tarafindan yapılmış olduğu iddia edebilir ${ }^{34}$.

Caminin çevresinde yer alan ahşap evler ile tek veya iki katlı dükkân dizilerinin de çevre yolu bağlantısını sağlamak amacıyla 1986 yılında yıkıldığı elde edilen raporlardan bilinmektedir. Caminin çevresinde yapılan düzenlemeler eski fotoğraflar aracılığıyla görülebilmektedir (G. 21-G. 25).

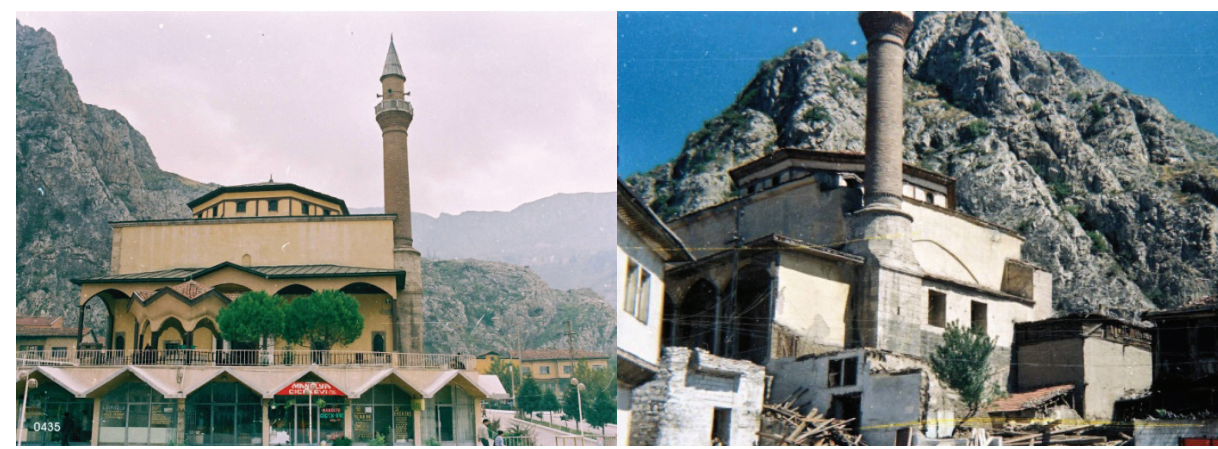

G. 21 ve G. 22: Caminin çevresine ait eski fotoğraf (Foto Apaydın Arşivi)

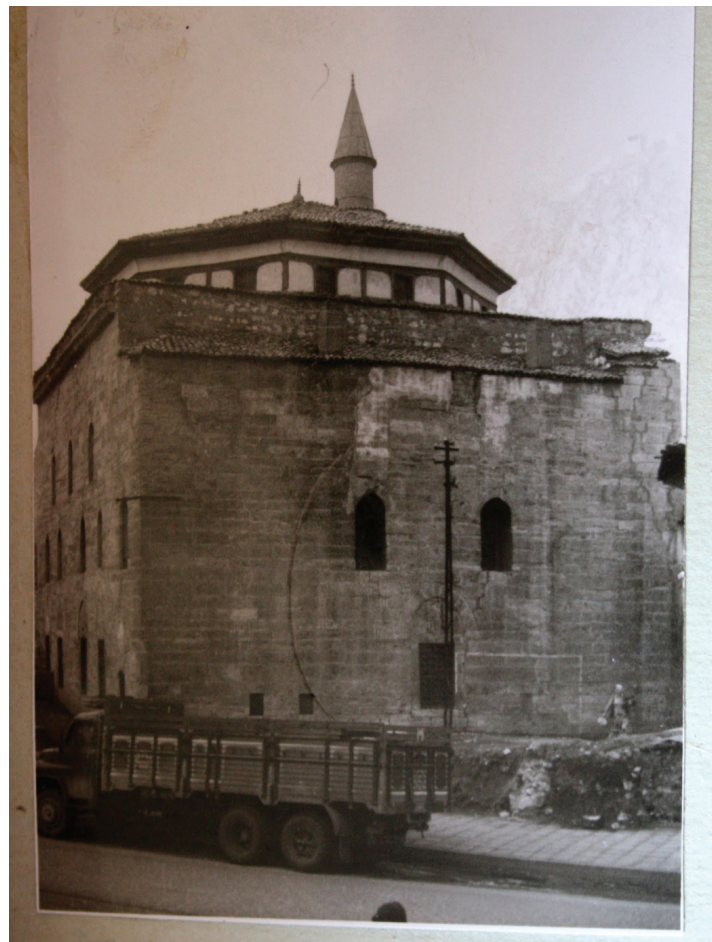

G. 23: Caminin doğu cephesine ait eski fotoğraf (Foto Apaydın Arşivi)

34 Rüçhan Arık, Batılılaşma Dönemi Anadolu Tasvir Sanatı, 80-83; Gönül Cantay, “Zileli Emin Usta'nın Bilinmeyen İki Eseri”, Bedrettin Cömert'e Armağan (Ankara: Hacettepe Üniversitesi Yayınları, 1980), 502. 


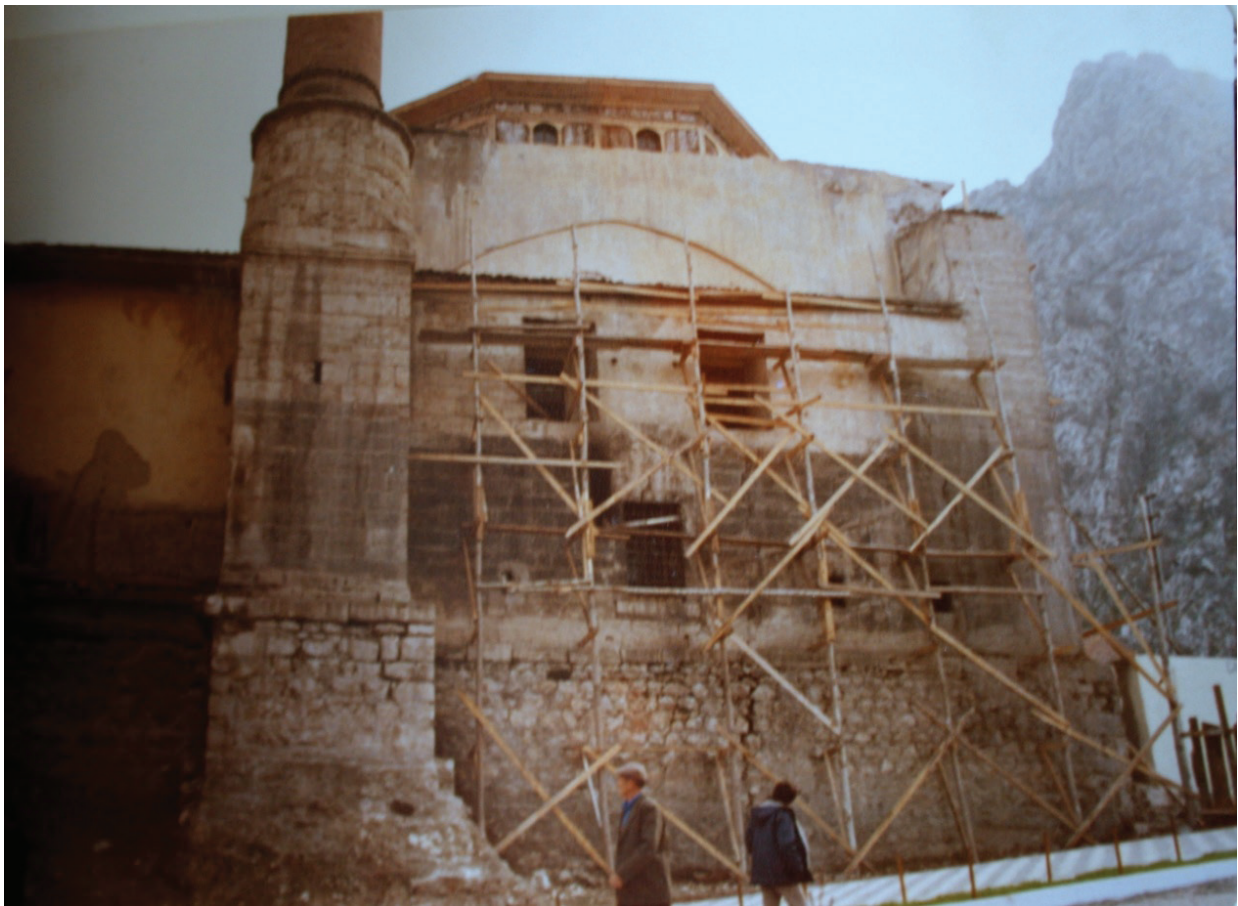

G. 24: Caminin batı cephesine ait eski fotoğraf (Foto Apaydın Arşivi)

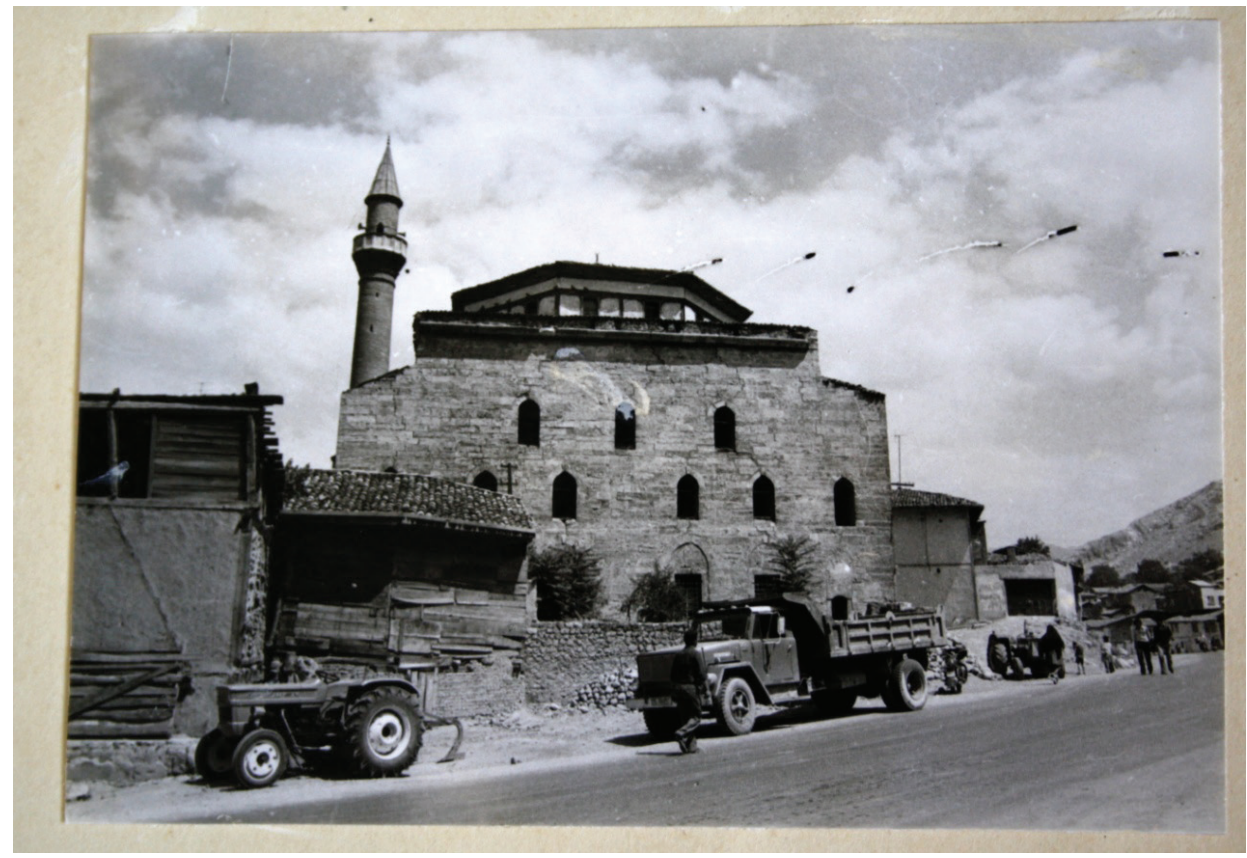

G. 25: Caminin çevresine ait eski fotoğraf (Foto Apaydın Arşivi) 


\section{Sonuç}

Camiyle ilgili yapılan kısıtlı sayıdaki çalışmalarda, caminin kitabesinde yer alan "mescid-i camii" ve "cami-i kebir" ifadelerine dayanarak caminin tek mekânlı, merkezî planlı bir cami olduğu iddia edilmiştir ancak yapının günümüzdeki planı, 1979 tarihli rölöve ve fotoğrafları yapının orijinalinde tabhaneli bir yapı olduğunu düşündürmektedir. Yapının doğu ve batı cephelerinde yer alan bu tabhane odalarının üst örtüsü, ana mekânın üst örtüsünden alt seviyede olup eğimli bir çatı şeklinde tasarlanmıştır. Cepheye hareketlilik katan bu eğimin hemen üzerinden sağır sivri bir kemer yükselmektedir. Yine 1979 tarihli plan rölövesinde gördügüümüz üzere caminin tabhane odaları tek katlı olup bu odalara giriş, harim kısmından ve son cemaat mahalline açılan küçük kapılardan sağlanmaktadır. Günümüzde güney doğu cephede yer alan kapının, orijinalinde pencere olduğu görülmektedir. Cami, bu yapısal özellikleri ile 15. yüzyıl zaviyeli camilerine benzerlik göstermektedir. Amasya' da inşa edilmiş başka zaviyeli cami örneklerinin bulunması ve Gümüşlü Cami’nin mekânsal özellikleri bu yapının zaviyeli bir cami olabileceğini düşündürmektedir.

Caminin son cemaat mahallinin özgün hâlinde nasıl olduğuna dair hiçbir veri bulunmamaktadır ancak yapısal izler ve dönemin üslupsal özelliklerine dayanarak bu mahallin, orijinalinde daha yüksek olduğu, kâgir malzeme ile inşa edildiği ve üzerinin beş adet kubbe ile örtülü olduğu iddia edebilir. Yapının harim kısmı üst örtüsünün de özgün hâlinde kubbe olduğu ileri sürebilir.

Caminin günümüze ulaşamayan özgün bezemeleri; bezeme programı, konuları ve üslubu açısından geç dönem özellikleri göstermektedir. Resimlerin üslupsal özellikleri yerel bir sanatçı olan Zileli Emin Usta'nın eserlerine benzerlik göstermesinden ve bahsi geçen sanatçının Amasya'da 1870'li yıllarda eserler vermesinden dolayı, Gümüşlü Cami duvar resimlerinin de 1870’li yıllarda Zileli Emin Usta tarafından yapıldığı iddia edilebilir.

Hakem Değerlendirmesi: Dış bağımsız.

Çıkar Çatışması: Yazar çıkar çatışması bildirmemiştir.

Finansal Destek: Yazar bu çalışma için finansal destek almadığını beyan etmiştir.

Peer-review: Externally peer-reviewed.

Conflict of Interest: The author has no conflict of interest to declare.

Grant Support: The author declared that this study has received no financial support.

\section{Kaynakça/References}

Abdi-zade Hüseyin Hüsameddin. Amasya Tarihi. Amasya: Amasya Belediyesi Kültür Yayınları. 1986.

Acar, Türkan. “Tabhaneli Camilerin Tipolojisi Üzerine Bir Deneme”, Süleyman Demirel Üniversitesi, Fen-Edebiyat Fakültesi Sosyal Bilimler Dergisi 28 (2013): 303-326.

Arık, Rüçhan. Batılılaşma Dönemi Anadolu Tasvir Sanatı. Ankara: Türkiye İş Bankası Kültür Yayınları. 1988. 
Arık, Rüçhan. "Osmanlı Sanatında Duvar Resimleri”. Osmanlı Kültür ve Sanat Ansiklopedisi. C. 11. Ankara: Yeni Türkiye Yayınları, 1999. 423- 436.

Arık, Rüçhan. "Sanatta Batılılaşma Sürecinde Balkan Anadolu Beraberliği”. Balkanlarda Kültürel Etkileşim ve Türk Mimarisi Sempozyumu Bildirileri, 17-19 Mayıs 2000, Şumnu (Bulgaristan). C. 1. Ankara: Atatürk Kültür Merkezi Yayınları, 2001, 71-96.

Avcı, Oğulcan. "Yozgat Başçavuşoğlu Camii ve Süslemeleri Üzerine Düşünceler". Osmanlı Mirası Araştırmaları Dergisi 5/3 (2016): 49-70.

Cantay, Gönül. “Zileli Emin Usta'nın Bilinmeyen İki Eseri”. Bedrettin Cömert'e Armağan. Ankara: Hacettepe Üniversitesi Yayınlar1, 1980, 497-507.

Çöl, Nilgün. "Kütahya İli Tavşanlı İlçesinde Kurşunlu Camiinin Duvar Resimlerinin Geleneksel Türk Duvar Resim Sanatı Çerçevesinde Değerlendirmesi: Osmanlı Sanatı Çerçevesinde Duvar Resmi”. Anadolu Üniversitesi Güzel Sanatlar Fakültesi Anadolu Sanat Dergisi 12 (2002): 49-66.

Eyice, Semavi. "İlk Osmanlı Devrinin Dini ve İçtimai bir Müessesi: Zaviyeler ve Zaviyeli Camiler". İstanbul Üniversitesi İktisat Fakültesi Mecmuası 1 (1962): 3-80.

Eyice, Semavi. "Beyazıd Paşa Cami, Amasya'da XV. Yüzyıl Başlarında Yapılan Cami”. TDV Íslam Ansiklopedisi. C. 5. Ankara: Türkiye Diyanet Vakfı Yayınları, 1992, 243-244.

Karakaya, Enis. “Çapanoğlu Camii Yozgat'ta XVIII. Yüzyılda Batı Üslubunda İnşa Edilen Cami”. TDV Íslam Ansiklopedisi. C. 8. Ankara: Türkiye Diyanet Vakfı Yayınları, 1993, 219-220.

Karakaya, Ebru. "Mehmed Paşa Külliyesi”. TDV İslam Ansiklopedisi. C. 28. Ankara: Türkiye Diyanet Vakfi Yayınları, 2003, 511-512.

Kınal, Füruzan. Eski Anadolu Tarihi. Ankara: Türk Tarih Kurumu Yayınları, 1962.

Menç, Hüseyin. Tarih İçinde Amasya. Amasya: Amasya Belediyesi Yayınları, 2014.

Renda, Günsel. Batılılaşma Döneminde Türk Resim Sanatı 1700- 1850. Ankara: Hacettepe Üniversitesi Yayınları, 1977.

Renda, Günsel. "Yenileşme Döneminde Kültür ve Sanat”. Türkler Ansiklopedisi. C. 15. Ankara: Yeni Türkiye Yayınları, 2002, 265-283.

Şahin, İlhan ve Feridun Emecen. “Amasya”. TDV İslam Ansiklopedisi. C. 3. Ankara: Türkiye Diyanet Vakfi Yayınları, 1991, 1-4.

Tanman, Baha. "Merzifon, Kara Mustafa Paşa Camii Şadırvanının Kubbesinde Zileli Emin'in Yarattı̆gı ‘Osmanlı Dünyası' ve Bu Dünyaya Yansıyan Kişiliği”. Sanat Tarihinde İkonografik Araştırmalar Güner Inal'a Armağan. Ankara: Hacettepe Üniversitesi Edebiyat Fakültesi Yayınlar1, 1993, 491-522.

Tekinalp, Pelin Şahin. "Batılılaşma Dönemi Duvar Resmi”. Türkler Ansiklopedisi. C. 15. Ankara: Yeni Türkiye Yayınları, 2002, 440-448.

Urak, Gediz. “Amasya'nın Türk Devri Şehir Dokusu ve Yapılarının Analiz ve Değerlendirilmesi”. Doktora Tezi, Gazi Üniversitesi, 1994.

\section{BELGELER}

V.G.M. 1981: 234 numaralı belge

V.G.M. 1985: 05.00 / 15 numaralı dosya

V.G.M. 1986: 05.00 / 15 numaralı dosya

V.G.M. 1986: 977 numaral1 belge

V.G.M. 2002: 1361 sayıl1 yazıs1 